\title{
Ecological Risk Assessment of Trace Elements Accumulated in Stormwater Ponds within Industrial Areas
}

Sylvia Waara ( $\sim$ sylvia.waara@hh.se )

Halmstad University: Hogskolan i Halmstad https://orcid.org/0000-0003-0553-7918

Frida Johansson

Halmstad University: Hogskolan i Halmstad

\section{Research Article}

Keywords: metals, metalloids, detention ponds, sediment quality, geoaccumulation index, risk quotients

Posted Date: May 20th, 2021

DOl: https://doi.org/10.21203/rs.3.rs-468037/v1

License: (c) (1) This work is licensed under a Creative Commons Attribution 4.0 International License.

Read Full License

Version of Record: A version of this preprint was published at Environmental Science and Pollution Research on December 21st, 2021. See the published version at https://doi.org/10.1007/s11356-021$18102-0$. 
1 Ecological risk assessment of trace elements accumulated in stormwater ponds within

2 industrial areas

3 Sylvia Waara ${ }^{1 *}$, Frida Johansson $^{1,2}$

$4 \quad 1^{*}$ Department of Environmental and Biosciences, Rydberg Laboratory of Applied Sciences, Halmstad 5 University, Box 823, 30118 Halmstad, Sweden, Email: sylvia.waara@hh.se

$62{ }^{2}$ Present address: SWECO AB, Halmstad, 30220 Halmstad, Sweden, Email: frida.johansson@sweco.se

$7 \quad{ }^{*}$ Corresponding author: Sylvia Waara, sylvia.waara@hh.se, phone +46729773608

8 Key words: metals, metalloids, detention ponds, sediment quality, geoaccumulation index, risk 9 quotients

\section{Acknowledgements}

11 This study was financially supported by the Municipality of Ängelholm. We thank Nikolina Ström and 12 Docent Karl-Otto Waara for their assistance with sampling. Dr David Green, University of Halmstad is 13 gratefully acknowledged for carefully reviewing the manuscript and for the assistance with the figures. 
Stormwater ponds can provide flood protection and efficiently treat stormwater using sedimentation. As the ponds also host aquatic biota and attract wildlife there is a growing concern that the sediment bound pollutants negatively affect aquatic organisms and the surrounding ecosystem. In this study we used three methods to assess the accumulation and the potential ecological risk of 13 different heavy metals and metalloids (e.g. trace elements) including both elements that are frequently monitored and some which are rarely monitored in sediment from 5 stormwater ponds located within catchments with predominately industrial activities. Ecological risk for organisms in the older ponds was observed for both commonly- (e.g. $\mathrm{Cd}, \mathrm{Cu}, \mathrm{Zn}$ ) and seldom- (e.g. $\mathrm{Ag}, \mathrm{Sb}$ ) monitored trace elements. The 3 methods ranked the degree of contamination similarly. We show that methods usually used for sediment quality assessment in aquatic ecosystems can also be used for screening the potential risk of other trace elements in stormwater ponds and may consequently be useful in stormwater monitoring and management. Our study also highlights the importance of establishing background conditions when conducting ecological risk assessment of sediment in stormwater ponds.

Introduction

Urban stormwater runoff may cause flooding and pollution in downstream watercourses if neither the flow is reduced nor the pollutants are removed (Baekken 1994, Maltby et al 1995; Blecken et al. 2012, Sharley et al. 2016). Today, stormwater is often retained and treated in wetlands or stormwater ponds (also called stormwater detention ponds or urban ponds), either alone or in combination with other techniques (Marsalek et al. 2005; Blecken et al. 2017; Jefferson et al. 2017; Sharley et al. 2017; Crane 2019). The type and quantity of pollutants in stormwater runoff which accumulates in a specific wetland or stormwater pond depends on the catchment area, climatic factors, land use and percentage impervious surfaces (Färm and Waara 2005; Casey et al. 2006; Frost et al. 2015; Søberg et al. 2016; Blecken et al. 2017; Sharley et al. 2017; Crane 2019).

Recently, concern has been raised over the ecological risks to aquatic life in wetlands and stormwater ponds and for the surrounding wildlife caused by the accumulated sediment. For example, Sharley et al. (2017) sampled 98 wetlands in the Melbourne region and found that catchments with $>10 \%$ industrial land use were at a greater risk of containing contaminants at values which exceeded ecological guideline values and waste disposal guidelines. Additionally, a study in Minnesota by Crane (2019) found that industrial areas in Minnesota were more contaminating than residential and commercial areas, leading to statistically significant increases in zinc and some organic micropollutant 
content in the studied stormwater ponds. This suggests that stormwater ponds in catchments with industrial activity may accumulate high levels of trace elements which could pose a significant risk to the ecosystem.

In studies of trace element accumulation in stormwater ponds, only a few selected heavy metals (e.g. $\mathrm{Cd}, \mathrm{Cu}, \mathrm{Ni}, \mathrm{Pb}, \mathrm{Zn}$ ) are typically monitored (Färm and Waara 2005; Casey et al. 2007; Egemose et al. 2015; Blecken et al. 2017; Sun et al. 2019). However, there are many other potentially ecologically harmful trace element contaminants. Herein, 13 different trace elements representing both commonly- and seldom- monitored trace elements were selected, and their accumulation in five ponds in catchments with industrial activity were studied. In addition, $\mathrm{P}$ and $\mathrm{S}$ were analysed to determine whether their concentrations correlated with those of the trace elements, and therefore if they could provide overall contamination values. The patterns and relationships between trace elements with P, S and sediment characteristics were analysed using Principal Component Analysis and Classification. Furthermore, three methods which are commonly used for assessing sediment quality in lakes and watercourses but rarely used for stormwater ponds and wetlands were used to assess the degree of contamination and ecological risk. The accumulation of elements in the ponds compared to background levels was assessed using Müller's geoaccumulation index, Igeo, (Müller 1969), while ecological risk was assessed using Håkanson's Potential Ecological Risk Index (RI) (Håkanson 1980) and by the Risk Quotient Methodology (RQ-method) (European Chemicals Bureau 2003) which nowadays, under REACH, is called Risk Characterisation Ratios (RCRs) (ECHA 2016) and therefore hereafter referred to as the RCR-method. To our knowledge, Igeo and RI have not been used to assess risk in stormwater pond sediment. The RCR-method is partly used as sediment guidelines, which in this study serve as PNEC values for calculating RCRs, are frequently compared to measured values when assessing the quality of stormwater sediment (Färm et al. 2003; Andersson et al. 2004; Färm and Waara 2005; Jang et al. 2010; Blecken et al. 2012; Allen et al. 2017; Sharley et al. 2017; Crane 2019). However, RCRs have not been calculated nor evaluated in previous studies. By combining the results from each method, the ponds at the highest risk and the trace elements of highest concern were identified and provided essential guidance for our continued contaminant monitoring.

\section{Materials and Methods}

\section{Study site}

The sampled stormwater ponds are in the municipality of Ängelholm in southern Sweden. The characteristics of the ponds and their catchment is presented in Table 1; and their design and sediment thicknesses are presented in Fig. 1. The ponds were designated Pond A and B (DUM 20 and DUM3, 


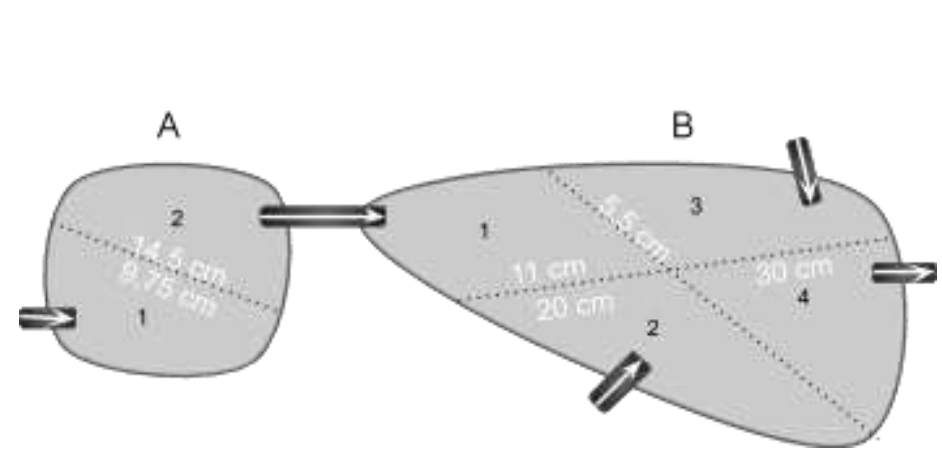

93

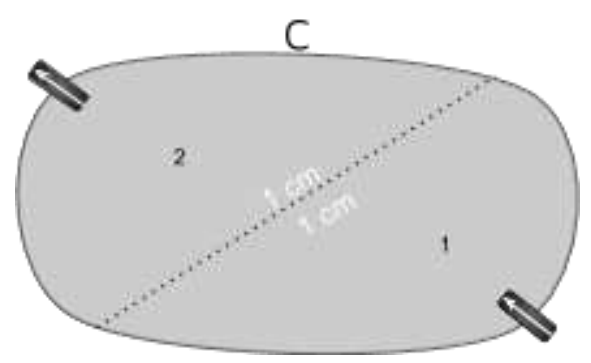

${ }^{1}$ the impervious surface will increase when the area is fully developed

${ }^{2}$ the pond was constructed after the development of the industrial area

Table 1 Characteristics of the investigated ponds. Data obtained from the Municipality of Ängelholm

\begin{tabular}{llllll}
\hline Pond & $\begin{array}{l}\text { Area } \\
\left(\mathbf{m}^{\mathbf{2}}\right)^{\mathbf{1}}\end{array}$ & $\begin{array}{l}\text { Catchment } \\
\text { area }(\mathbf{h a})^{\mathbf{2}}\end{array}$ & $\begin{array}{l}\text { \% } \\
\text { Impervious } \\
\text { surface }^{\mathbf{1}}\end{array}$ & $\begin{array}{l}\text { The ratio (in } \\
\text { percentage) of } \\
\text { pond area to } \\
\text { impervious area }\end{array}$ & $\begin{array}{l}\text { Age 2019 } \\
\text { (years) }\end{array}$ \\
\hline A (DUM 20) & 300 & 6.5 & 50 & 0.9 & 6 \\
B (DUM 3) & 950 & 72.0 & 50 & 0.3 & 17 \\
C (DUM 23) & 2000 & 14.5 & $12^{1}$ & 1.1 & 2 \\
D (DUM 8) & 1300 & 44.3 & 30 & 1.0 & 18 \\
E (DUM 19) & 500 & 24.8 & $70^{2}$ & 0.3 & 2 \\
\hline
\end{tabular}

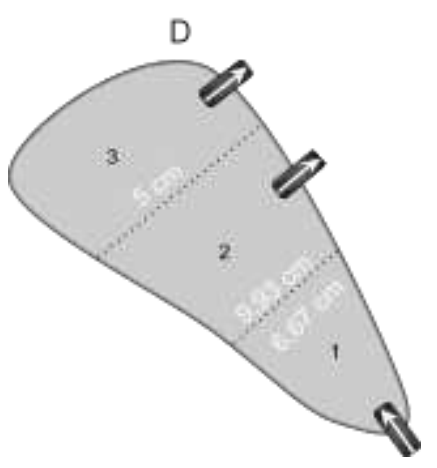

Fig 1 Design of the ponds and the measured thickness of sediment 
Sediments were first sampled in April 2019. Each pond was split into as many sections as there were inlets and outlets (Fig. 1), which enabled the identification of differences in sediment characteristics and pollutant levels within a single pond. Sediment depth and sample collection was conducted using the method described by Blecken et al. (2017). Briefly, sediment samples were taken with a sediment retriever. The depth of the accumulated sediment layer (i.e. only that which was above the clay layer) was measured with a ruler while the extracted core was still in the retriever. After the sediment sample was emptied into a clean bucket, the clay layer was carefully removed, and the remaining sample was mixed thoroughly with the other 3-6 subsamples collected from the same pond section. The number of subsamples taken from each section was dependent on the section area.

In August 2019, surface soil around the ponds $A+B, C$ and $E$ and well above possible waterlines was collected to determine background element concentrations in soil which in this area is dominated by kaolinite clay mineral. Subsurface soil was collected randomly using a small clean spoon and then mixed thoroughly before analysis. At this time, a sample from E3 was also taken as it was not possible to retrieve a sample with the core sampler during the first sampling because this part of the pond is covered with macadam. Additionally, although no accumulation of sediment was evident above the macadam, it was possible to collect the material deposited around and under the macadam layer and around the macrophyte roots using a gloved hand in order to avoid sampling the underlying clay layer.

The particle size distribution of the samples was determined according to ISO 11277:2009 "Soil quality - Determination of particle size distribution in mineral soil material - Method by sieving and sedimentation". The determination of dry matter was conducted according to Swedish Standard (SS) 28113 "Determination of dry matter and ignition residue in water, sludge and sediment". The elemental composition of the samples was analysed with inductively coupled plasma sector field mass spectroscopy (ICP-SFMS). In all cases, samples were digested in concentrated acid. For the elements $\mathrm{As}, \mathrm{Ba}, \mathrm{Cd}, \mathrm{Co}, \mathrm{Cr}, \mathrm{Cu}, \mathrm{Hg}, \mathrm{Ni}, \mathrm{P}, \mathrm{Pb}, \mathrm{S}, \mathrm{V}$ and $\mathrm{Zn}$, samples were heated and mixed in concentrated $\mathrm{HNO}_{3}$;

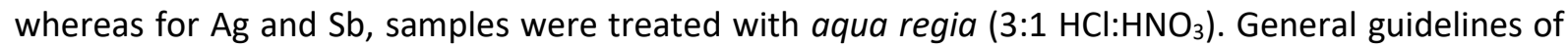
the method are found in SS EN ISO 17294-1 "Water quality - Application of inductively coupled plasma mass spectrometry (ICP-MS) - Part 1: General guidelines." Analysis was conducted according to ISO 17294-2:2016 "Water quality - Application of inductively coupled plasma mass spectrometry (ICPMS) - Part 2: Determination of selected elements including uranium isotopes (modified)" and USA EPA 200.8 "Determination of Trace Elements in Waters and Wastes by Inductively Coupled PlasmaMass Spectrometry". All analyses were carried out by a certified laboratory. 
127 The division of trace elements into commonly-monitored (i.e. $\mathrm{Cd}, \mathrm{Cr}, \mathrm{Cu}, \mathrm{Hg}, \mathrm{Ni}, \mathrm{Pb}, \mathrm{Zn}$ ) and seldom-

128 monitored ( $\mathrm{Ag}, \mathrm{As}, \mathrm{Ba}, \mathrm{Co}, \mathrm{Sb}, \mathrm{V})$ was related to the frequency the elements were quantified in

129 literature studies such as those presented in Table 5.

130

131

132

133

134

135

136

137

138

139

140

141

142

143

144

145

146

Data analysis

Calculations and statistical analyses were conducted using Statistica 13.5.0.17, TIBCO Software Inc. Multivariate analysis was conducted using the module Principal Component Analysis and Classification. Computational details are described in the software in the document "Principal Components \& Classification Analysis - Computational Details".

Determination of the contamination degree using the geoaccumulation index (Igeo)

The single element geoaccumulation index, $I_{g e o}$, developed by Müller (1969) is generally used for comparing current metal levels in sediment to pre-industrial levels (Zhu et al. 2013; Manoy and Padhy 2014; Duodo et al. 2016; Wang et al. 2016; Wang et al. 2018; Li et al. 2020). It is calculated using Equation 1:

$$
I_{g e o}=\log _{2}\left(\frac{C_{i}}{1.5 \times B_{i}}\right)
$$

where $c_{i}$ is the measured concentration of the examined metal in the sediment, and $B_{i}$ is the geochemical background concentration. Here $B_{i}$ was calculated as the average value obtained from three soil samples taken around ponds $A+B, C$ and $E$. An adjustment factor of 1.5 was used to account for possible variations in background values as well as minor anthropogenic influences. Müller (1969) used a graded scale of classification (Table 2):

Table 2 Classification of $I_{\text {geo }}$ (Müller 1969)

\begin{tabular}{lll}
\hline Class & Description & $I_{\text {geo }}$ value \\
\hline 0 & Unpolluted & $I_{\text {geo }} \leq 0$ \\
1 & Slightly polluted & $0<I_{\text {geo }} \leq 1$ \\
2 & Moderately polluted & $1<I_{\text {geo }} \leq 2$ \\
3 & Moderately/severely polluted & $2<I_{\text {geo }} \leq 3$ \\
4 & Severely polluted & $3<I_{\text {geo }} \leq 4$ \\
5 & Severely/Extremely polluted & $4<I_{\text {geo }} \leq 5$ \\
6 & Extremely polluted & $I_{\text {geo }}>5$ \\
\hline
\end{tabular}

147 The sum of the average $I_{g e o}$ values for all trace elements determined in each pond were calculated and

148 used to generate a risk ranking for each respective pond. These values were then compared to values

149 obtained from two other risk ranking methods described below. Negative values (i.e. unpolluted; class

150 0) were set to zero. 
The RI method was developed by Håkanson (1980) for assessing the potential ecological risks in sediment in freshwater ecosystems in Sweden. This was determined from the quantity of 7 elements ( $\mathrm{As}, \mathrm{Cd}, \mathrm{Cr}, \mathrm{Cu}, \mathrm{Hg}, \mathrm{Pb}$ and $\mathrm{Zn}$ ) and one persistent organic pollutant (PCB); and continues to be used for ecological risk assessments of heavy metals in sediments (Manoj and Padhy 2014; Duodu et al. 2016; Jiao et al. 2017; Wang et al. 2018; Zhuang et al. 2018; Wei et al. 2019; Li et al. 2020). The RI method considers the hazard of metals to humans and ecosystems from two aspects - the abundance principle and the release effect - where the potential toxicity of a metal is inversely proportional to its abundance. The index includes the risk factor, $E r^{i}$, for a given substance (Equation 2), the sum of which being the Potential Ecological Risk Index (RI) (Equation 4; Håkanson 1980):

$$
E r^{i}=\operatorname{Tr}^{i} x C_{f}^{i}
$$

(Equation 2)

$$
C_{f}^{i}=\frac{C_{o}^{i}}{C_{n}^{i}}
$$

$$
R I=\sum_{i}^{n} E_{r}^{i}=\sum_{i}^{n} T_{r}^{i} x C_{f}^{i}
$$

(Equation 4)

164 where $\operatorname{Tr}^{i}$ is the toxic response factor of substance $i, C_{f}^{i}=$ is the contamination factor of substance $i$, $C_{o}^{i}$ is the concentration of substance $i$ in the sediment, and $C_{n}^{i}=$ concentration of substance $i$ in the background.

Here, $C_{f}^{i}$ was calculated as the average value obtained from 3 soil samples taken around ponds $A+B, C$ and $\mathrm{E}$. The toxic response factors $(\mathrm{Tr})$ for each element were obtained from previously published studies (Table 3). For a single substance, the risk factor value (Er) and the sum of risk factors (RI) were classified according to (Håkanson 1980, Table 4). 


\begin{tabular}{lll}
\hline Element & Tr & Source \\
\hline $\mathrm{Ag}$ & 17.5 & Aksu et al. 1998 \\
$\mathrm{As}$ & 10 & Håkanson 1980 \\
$\mathrm{Ba}$ & 2 & Yang et al. 2015 \\
$\mathrm{Cd}$ & 30 & Håkanson 1980 \\
$\mathrm{Co}$ & 5 & Zhang et al. 2017 \\
$\mathrm{Cr}$ & 2 & Håkanson 1980 \\
$\mathrm{Cu}$ & 5 & Håkanson 1980 \\
$\mathrm{Ni}$ & 5 & Zhang et al. 2017 \\
$\mathrm{Pb}$ & 5 & Håkanson 1980 \\
$\mathrm{Sb}$ & 7 & Wang et al. 2018 \\
$\mathrm{V}$ & 2 & Zhu et al. 2013 \\
$\mathrm{Zn}$ & 1 & Håkanson 1980 \\
\hline
\end{tabular}

173

Table 4 Classification of Potential Ecological Risk Index (Håkanson 1980)

\begin{tabular}{llll}
\hline $\begin{array}{l}\text { Level of potential ecological } \\
\text { risk }\end{array}$ & $\boldsymbol{E r}^{i}$ value & $\begin{array}{l}\text { Level of ecological } \\
\text { risk }\end{array}$ & $\boldsymbol{R I}$ value \\
\hline Low & $E r^{i}<40$ & Low & $\mathrm{RI}<150$ \\
Moderate & $40 \leq E r^{i}<80$ & Moderate & $150 \leq \mathrm{RI}<300$ \\
Considerable & $80 \leq E r^{i}<160$ & Considerable & $300 \leq \mathrm{RI}<600$ \\
High & $160 \leq E r^{i}<320$ & & \\
Very high & $E r^{i} \geq 320$ & Very high & $\mathrm{RI} \geq 600$ \\
\hline
\end{tabular}

Ecological risk assessment using the risk characterisation ratio method (RCR-method)

177 The derivation of RCRs (the term Risk Quotients is also commonly used) for assessing ecological risk is 178 used in many fields, such as for evaluating the risk of chemicals within the EU (ECHA 2016), the risk of emerging pollutants in landfill leachate (Nika et al. 2020), or the potential risk of pharmaceuticals in surface waters (Zhou et al. 2019). The RCR is derived by dividing the Predicted or Measured Environmental Concentration (PEC or MEC, respectively) by the Predicted No Effect Concentration (PNEC), where a RCR $\geq 1$ indicates a risk of deleterious effects to the ecosystem by the pollutant in question. The PNEC is usually derived using toxicity data for sediment dwelling organisms, but where this data is lacking other methods such as the Equilibrium Partitioning Model which use toxicity data for pelagic species can be used (CIS 2011). PNEC values are often generated when Environmental Quality Standards are set, such as those under the Environmental Quality Standard Directive of the EU (Directive 2013/39/EU). In this study, we use data from when EQS were set for metals and metalloids in water, soil and sediment in the Netherlands (Crommentuijn et al. 2000); as equivalent data are still lacking for most sediment contaminants in Swedish and European legislation. Models and data from 
190

191

192

the Netherlands have also been used for developing guideline values for contaminated soil in Sweden (Swedish Environmental Protection Agency 2009). An RCR was consequently calculated using Equation 5:

$$
R C R_{i}=\frac{M E C_{i}}{N C_{i}}
$$

Where $R C R_{i}$ is the risk characterisation ratio for element $i, M E C_{i}$ is the measured concentration of element $i$ in the sample, and $N C_{i}$ is the negligible concentration of element $i$. Values for $N C_{i}$ were calculated using the modified Eq-P method; and take into account mixture effects. Elements at concentrations lower than or equal to their $N C$ is not expected to cause negative long-term effects in the ecosystem (Crommentuijn et al. 2000). NCs were available for all trace elements except Ag, for which the Danish Default Guideline Value (DGV) of $1.5 \mathrm{mg}$ per $\mathrm{kg}$ of dry weight $(\mathrm{mg} / \mathrm{kg} \mathrm{DW}$ ) for sediments was used as PNEC value (Ministry of Environment and Food of Denmark. 2017).

The sum of average RCR values for all trace elements in each pond were calculated to enable risk ranking with $I_{g e o}$ and $\mathrm{RI}$.

\section{Remediation requirements}

The samples were also classified using the generic guideline values for contaminated soil developed by the Swedish Environmental Protection Agency (2009) using the guideline values in the updated list from 2016 (Swedish Environmental Protection Agency 2016). Generic guideline values were available for all trace elements except $\mathrm{Ag}$ (Supplementary Data Table S1). Two different generic guideline values are derived depending upon expected land use, sensitive land use (KM) and less sensitive land use (MKM). KM values are used for example if the land is going to be used for housing while MKM values are used if the land use is intended for industries.

\section{Results and discussion}

\section{Concentrations of elements in sediment}

The concentrations for elements at all sampling sites and the average values for each element in each pond are presented in Supplementary Data Table S2. The measured concentrations of four commonlymonitored ( $\mathrm{Cd}, \mathrm{Cu}, \mathrm{Pb}$ and $\mathrm{Zn}$ ) and four seldom-measured ( $\mathrm{Ag}, \mathrm{As}, \mathrm{Ba}$ and $\mathrm{Sb}$ ) trace elements in stormwater ponds are presented in Fig. 2 and Fig. 3, respectively. For all elements, the highest concentrations were recorded in the older ponds ( $A, B$ and $D$ ) while the concentrations in recently constructed ponds ( $\mathrm{C}$ and $\mathrm{E}$ ) were generally low or close to the concentration found in the surrounding 
soil. The mean element concentrations were ranked as follows: $\mathrm{P}>\mathrm{S}>\mathrm{Zn}>\mathrm{Ba}>\mathrm{Cu}>\mathrm{V}>\mathrm{Pb}>\mathrm{Cr}>\mathrm{Ni}$ $>\mathrm{Co}>\mathrm{As}>\mathrm{Sb}>\mathrm{Cd}>\mathrm{Ag}$. Measured concentrations for Hg never exceeded the detection limit $(0.5$ $\mathrm{mg} / \mathrm{kg} \mathrm{DW}$ ), while $\mathrm{Ag}$ was below the detection limit $(0.7 \mathrm{mg} / \mathrm{kg} \mathrm{DW})$ in sediments from pond $\mathrm{C}$ and $\mathrm{E}$.

222

The element concentrations were generally similar or higher at the outlets compared to the inlets of ponds. For pond A, samples from near the outlet had higher concentrations for all elements compared to the inlet except for S. In pond B, all elements were found in higher concentrations near the outlet, except for $\mathrm{Co}, \mathrm{Cr}$ and $\mathrm{V}$ which were in a higher concentration around inlet $\mathrm{B} 2$. In pond $\mathrm{D}$, all elements were found in higher concentrations at outlet $\mathrm{D} 3$ compared to the inlet, but only $\mathrm{Cd}, \mathrm{Cu}, \mathrm{Pb}, \mathrm{S}$ and $\mathrm{Zn}$ were higher in concentration at outlet D2 compared to the inlet. In pond E, element concentrations, except for $\mathrm{Ag}, \mathrm{Co}, \mathrm{Cu}, \mathrm{S}$ and $\mathrm{Sb}$, were generally higher at the outlet than at the inlets. Inlet E2 presented the highest concentration of $\mathrm{Co}$ and $\mathrm{Cu}$, while inlet $\mathrm{E} 1$ had the highest concentrations of $\mathrm{Ag}, \mathrm{S}$ and $\mathrm{Sb}$. Finally, in pond $\mathrm{C}$, a different trend was observed where $\mathrm{Ag}$ was below the detection limit and all other element concentrations - except for those of $\mathrm{Ba}, \mathrm{Cr}$ and $\mathrm{V}$ - were higher at the inlet than the outlet.

Our measured trace element concentrations were then compared with data from other studies (Table 5). The concentrations of commonly-monitored trace elements (i.e. $\mathrm{Cd}, \mathrm{Cr}, \mathrm{Cu}, \mathrm{Ni}, \mathrm{Pb}, \mathrm{Zn}$ ) were detected within the same order of magnitude as those observed in several previous international and national studies (Jang et al. 2010; Blecken et al. 2012; 2017; Istenič et al. 2012; Egemose et al. 2015; Frost et al. 2015; Sharley et al. 2017; Crane 2019; Sun et al. 2019), but lower maximum concentration values were obtained here compared to those found in ponds within industrial areas (Sharley et al. 2017). Blecken et al. (2012) also detected six-fold higher $\mathrm{Cr}$ concentrations in sediment close to stormwater outlets, while Jang et al. (2010) observed four-fold higher maximum values in road residues. The concentration values for seldom-monitored metals (i.e. $\mathrm{Ag}, \mathrm{As}, \mathrm{Ba}, \mathrm{Co}, \mathrm{Sb}, \mathrm{V}$ ) were also within the same order of magnitude as previously reported values (Färm et al. 2003; Jang et al. 2010; Frost et al. 2015; Sharley et al. 2017; Crane 2019). Furthermore, higher maximum concentration values for these elements were found in stormwater ponds and tunnels within industrial areas (Färm et al. 2003; Sharley et al. 2017). Jang et al. (2010) generally observed lower maximum values in sediment from stormwater ponds but the maximum concentrations of Ba was higher. 


\section{Cadmium}

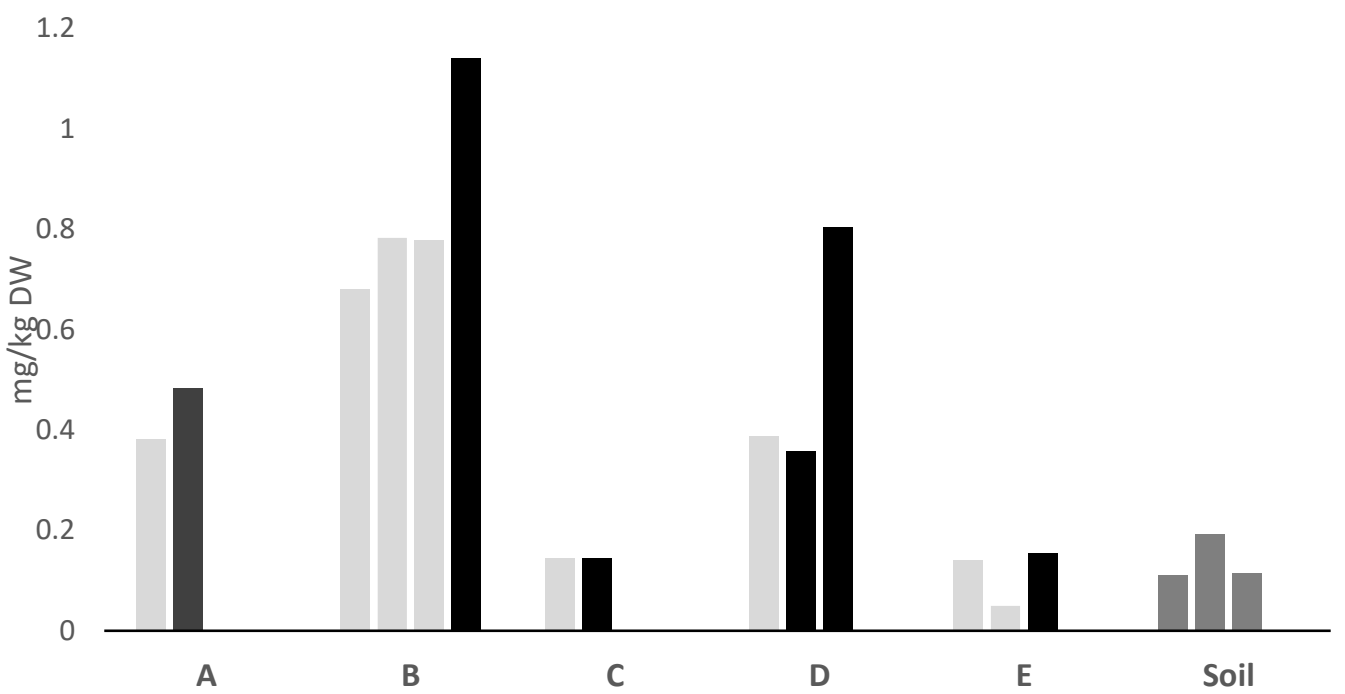

247

249

250

\section{Copper}

140

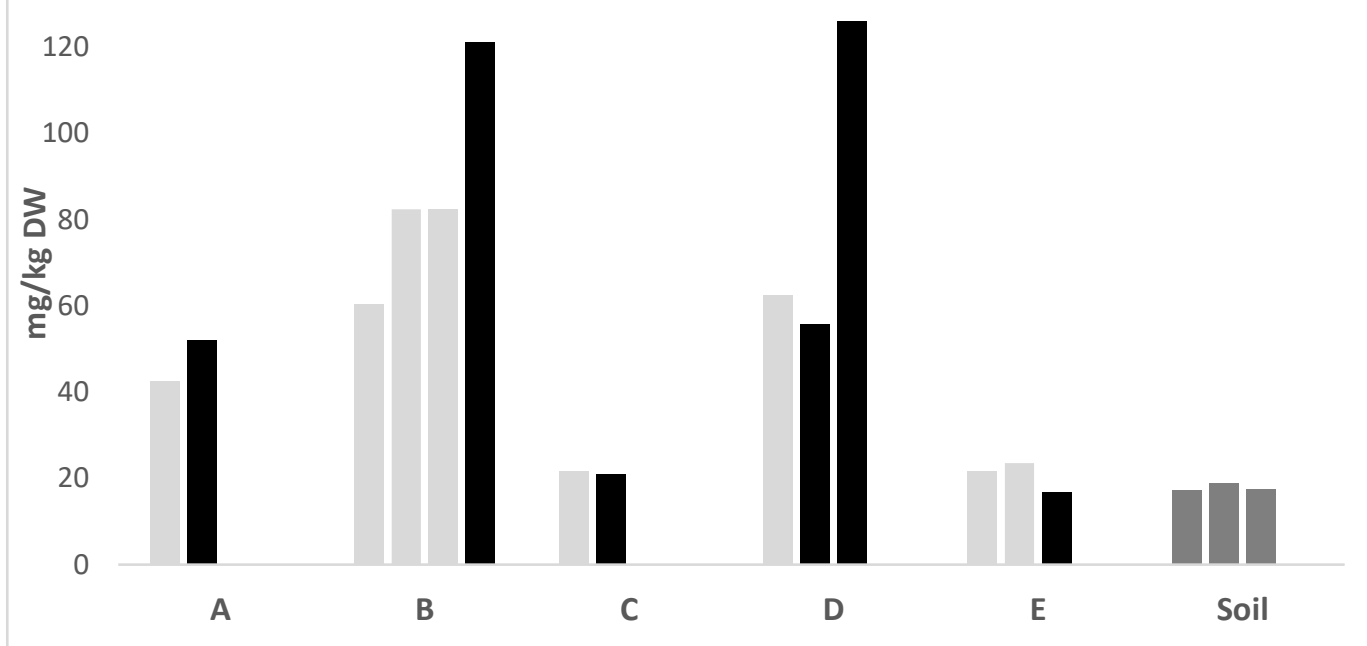

251

252 


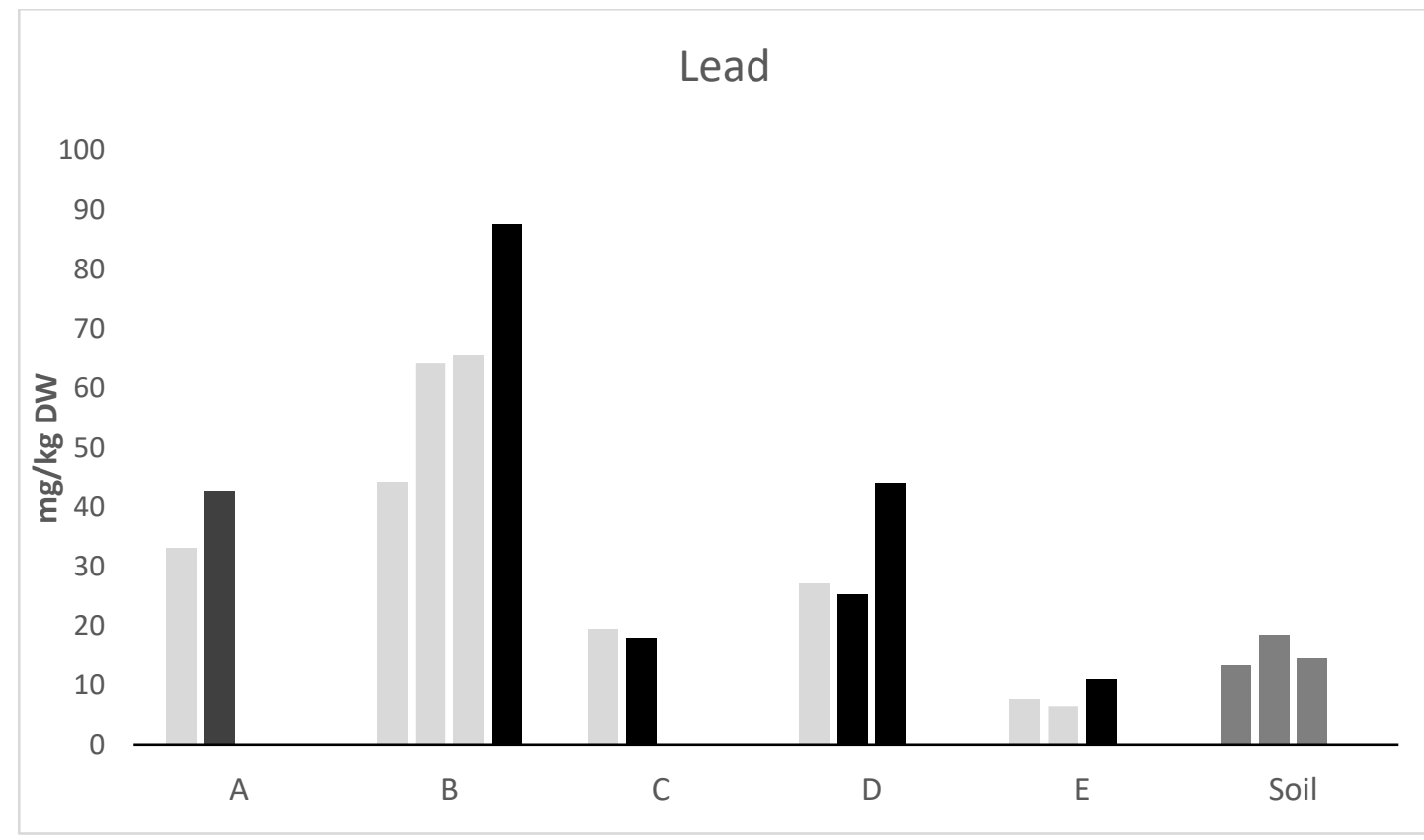

254

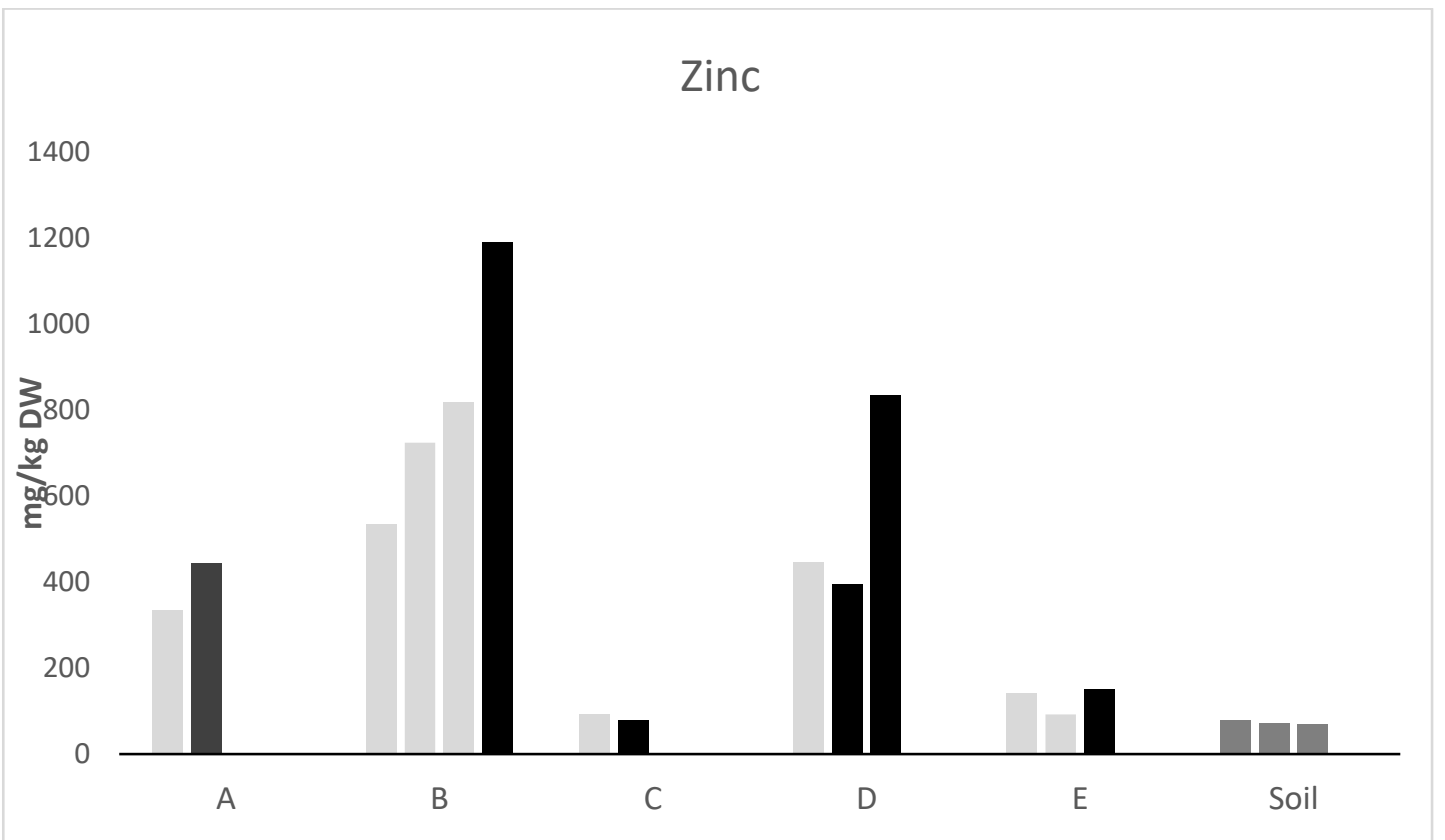

255

Fig. 2 Concentrations of four commonly-monitored trace elements ( $\mathrm{Cd}, \mathrm{Co}, \mathrm{Pb}, \mathrm{Zn}$ ) in sediments in stormwater ponds and soil from the banks of the ponds in areas with industrial activity. Light grey bars - inlets, black bars-outlets. 
Silver

260

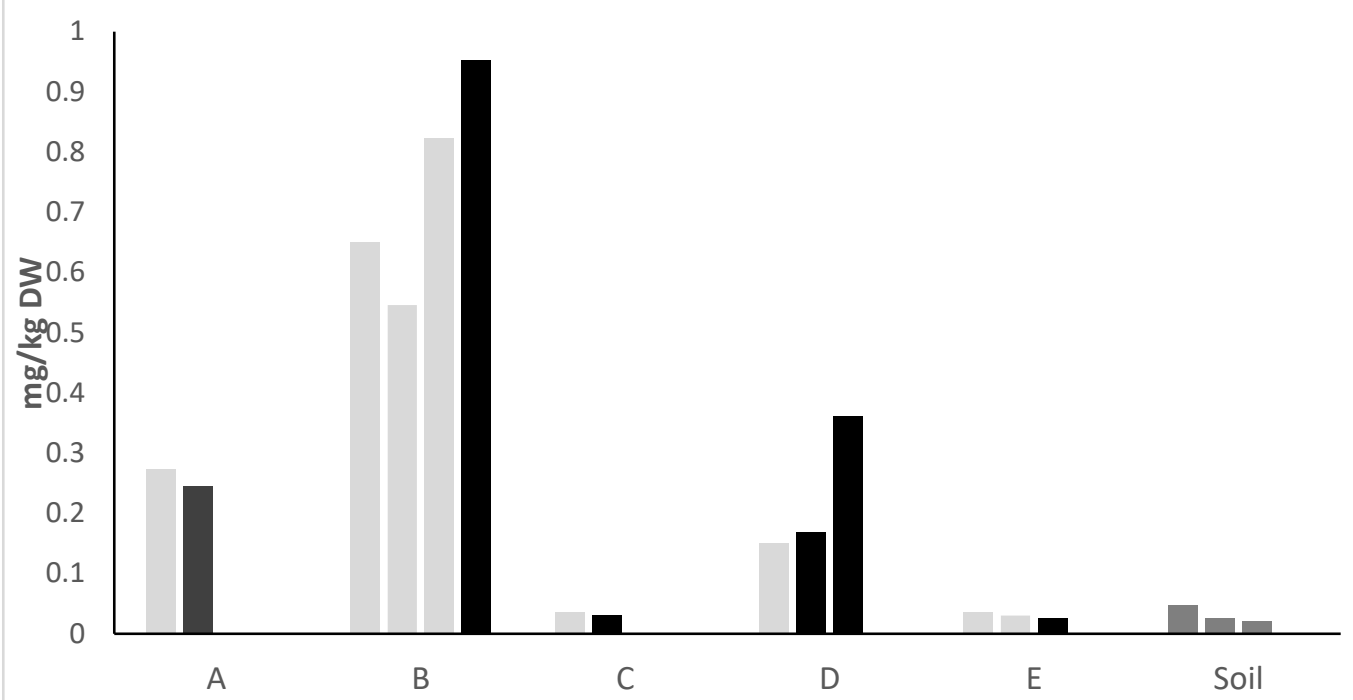

Arsenic

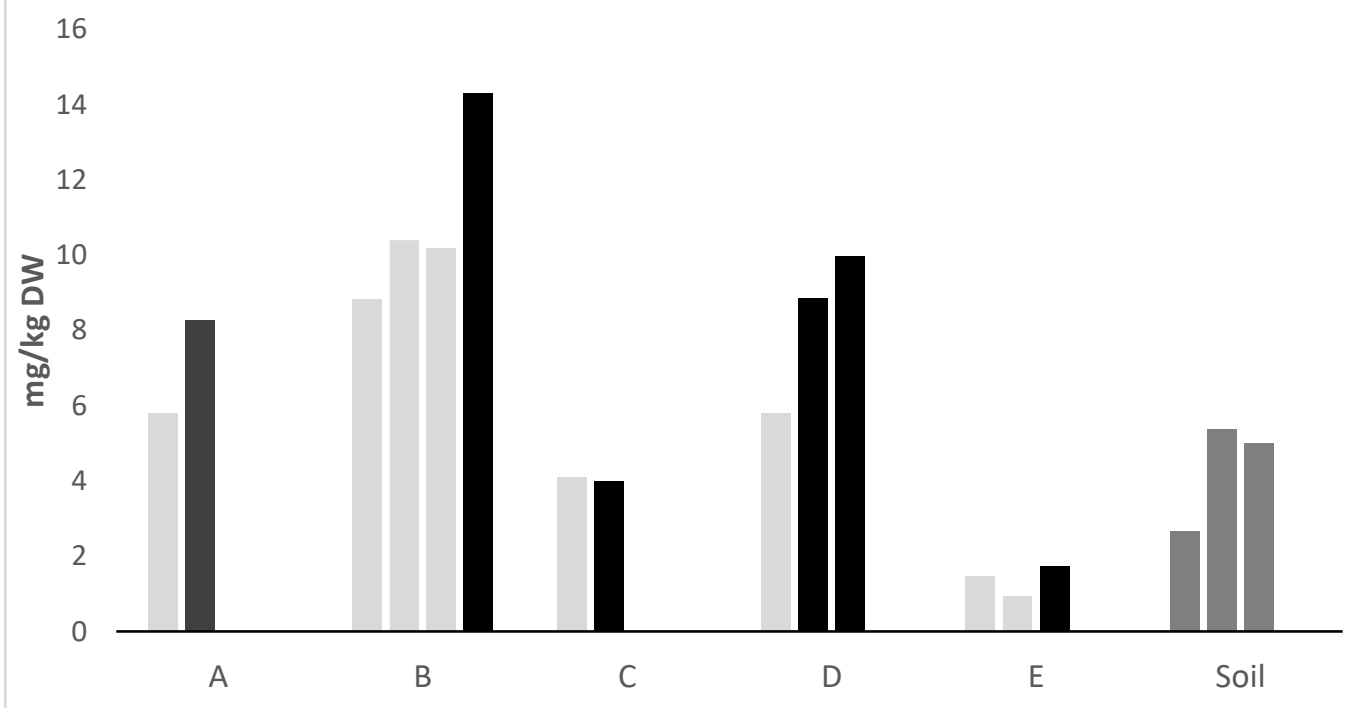




\section{Barium}

225

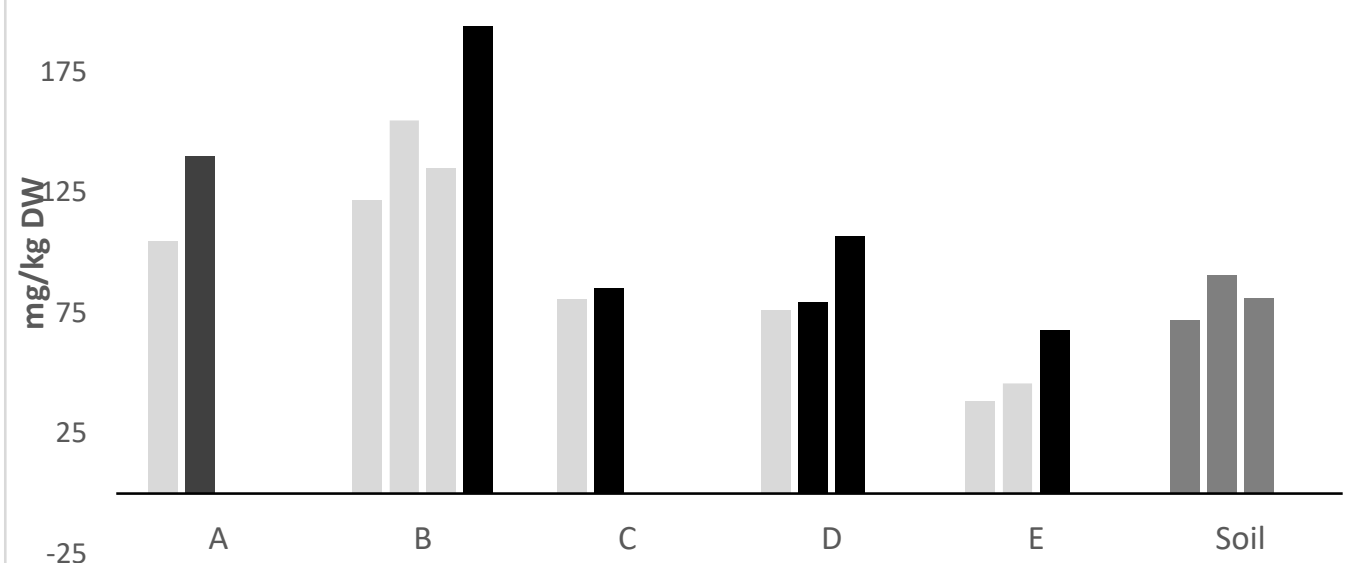

262

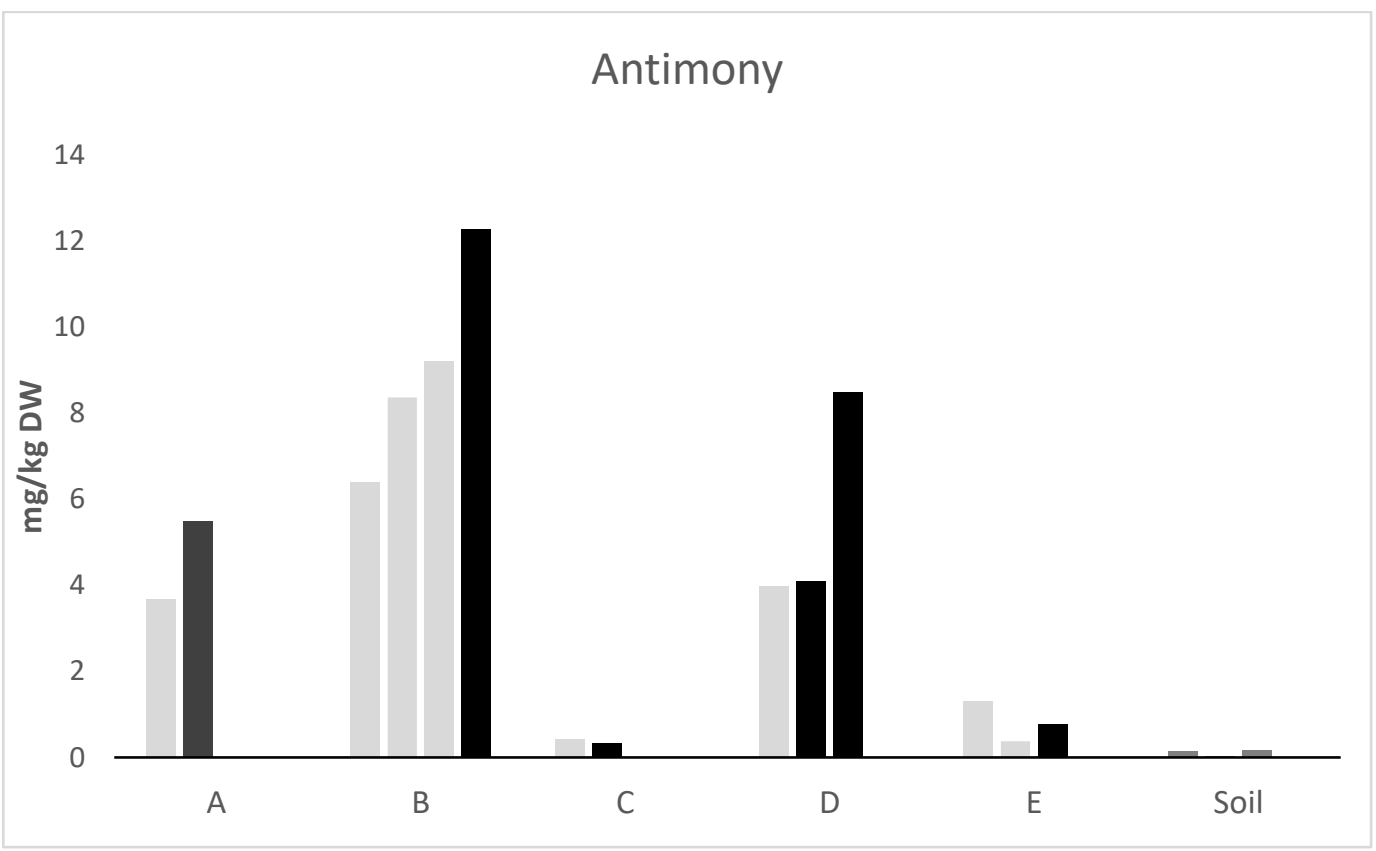

Fig. 3 Concentrations of four seldom monitored trace elements ( $\mathrm{Ag}, \mathrm{As}, \mathrm{Ba}, \mathrm{Sb})$ in sediment in stormwater ponds and soil from the banks of the ponds in areas with industrial activity. Light grey bars - inlets, black bars-outlets 
Table 5 Concentrations of trace elements in sediments from stormwater ponds, outlets and stormwater tunnels. Data is for stormwater ponds if not stated.

Min-max values are presented or if not available mean \pm standard deviation is used, $n . a .=$ not analysed. $\mathrm{N}=$ the number of ponds studied

\begin{tabular}{|c|c|c|c|c|c|c|c|c|c|c|c|c|c|}
\hline $\begin{array}{l}\text { Referen- } \\
\text { ce }\end{array}$ & $\mathrm{Ag}$ & As & $\mathrm{Ba}$ & Cd & Co & $\mathrm{Cr}$ & $\mathrm{Cu}$ & $\mathrm{Hg}$ & $\mathrm{Ni}$ & $\mathrm{Pb}$ & $\mathrm{Sb}$ & $\mathbf{V}$ & Zn \\
\hline $\begin{array}{l}\text { This } \\
\text { study } \\
\mathrm{N}=5\end{array}$ & $\begin{array}{l}0.030- \\
0.952\end{array}$ & $\begin{array}{l}0.9- \\
14.3\end{array}$ & $\begin{array}{l}39- \\
194\end{array}$ & $0.05-0.80$ & $\begin{array}{l}3.5- \\
13.2\end{array}$ & $\begin{array}{l}9.0- \\
45.6\end{array}$ & $\begin{array}{l}20.9- \\
126.0\end{array}$ & $<0.5$ & $\begin{array}{l}6.4- \\
34.9\end{array}$ & $\begin{array}{l}6.5- \\
87.6\end{array}$ & $\begin{array}{l}0.325- \\
12.3\end{array}$ & $\begin{array}{l}15.9- \\
75.3\end{array}$ & $\begin{array}{l}78.6- \\
1190\end{array}$ \\
\hline $\begin{array}{l}\text { Crane } \\
2019 \\
\mathrm{~N}=15\end{array}$ & $\begin{array}{l}0.99 \pm \\
2.4\end{array}$ & $\begin{array}{l}5.5 \pm \\
2.3\end{array}$ & $\begin{array}{l}147 \pm \\
43\end{array}$ & $1.5 \pm 0.57$ & $\begin{array}{l}8.2 \pm \\
2.8\end{array}$ & $\begin{array}{l}42.0 \pm \\
14.7\end{array}$ & $\begin{array}{l}31.6 \pm \\
10.1\end{array}$ & $\begin{array}{l}0.059 \\
\pm \\
0.022 \\
\end{array}$ & $\begin{array}{l}23.3 \pm \\
7.2\end{array}$ & $\begin{array}{l}39.2 \pm \\
25.5\end{array}$ & $<1.2$ & $\begin{array}{l}45.3 \pm \\
11.7\end{array}$ & $\begin{array}{l}154.3 \pm \\
79.7\end{array}$ \\
\hline $\begin{array}{l}\text { Sun et al. } \\
2019 \\
N=12\end{array}$ & n.a. & n.a. & n.a. & n.a. & n.a. & $15-86$ & $18-200$ & n.a. & $17-110$ & 9.9-76 & n.a. & n.a. & $57-850$ \\
\hline $\begin{array}{l}\text { Blecken } \\
\text { et al. } \\
2017 \\
N=25\end{array}$ & n.a. & n.a. & n.a. & $<0.1-2.3$ & n.a. & $2-81$ & $3-109$ & n.a. & $2-39$ & $3-77$ & n.a. & n.a. & $14-597$ \\
\hline $\begin{array}{l}\text { Sharley } \\
\text { et al. } \\
2017 \\
N=98\end{array}$ & $<2-6$ & $<5-51$ & $\begin{array}{l}40- \\
430\end{array}$ & $<1-11$ & $2-31$ & $12-121$ & 6-1090 & $\begin{array}{l}<0.1- \\
2.9\end{array}$ & $4-159$ & $9-456$ & $<5-17$ & $14-130$ & $12-4940$ \\
\hline $\begin{array}{l}\text { Ege- } \\
\text { mose et } \\
\text { al. } 2015 \\
N=37\end{array}$ & n.a. & n.a. & n.a. & $0.1-1.4$ & n.a. & $18-62$ & $18-62$ & n.a. & $18-62$ & $18-62$ & n.a. & n.a. & $166-451$ \\
\hline $\begin{array}{l}\text { Frost et } \\
\text { al. } 2015\end{array}$ & $0.04-0.37$ & n.a. & $\begin{array}{l}64.7- \\
507.3 \\
\end{array}$ & $0.06-0.39$ & $\begin{array}{l}3.8- \\
20.3 \\
\end{array}$ & $\begin{array}{l}9.6- \\
60.5 \\
\end{array}$ & $9.5-42.3$ & n.a. & $\begin{array}{l}6.6- \\
45.4 \\
\end{array}$ & $6.0-38.1$ & n.a. & $14.3-67.5$ & $\begin{array}{l}35.5- \\
175.4 \\
\end{array}$ \\
\hline $\begin{array}{l}\text { Blecken } \\
\text { et al. } \\
2012 \\
\mathrm{~N}=32 \\
\end{array}$ & n.a. & n.a. & n.a. & $0.15-1.23$ & $\begin{array}{l}3.8- \\
25.0\end{array}$ & $64-307$ & $17-263$ & n.a. & $10-50$ & $8-42$ & n.a. & n.a. & $68-470$ \\
\hline $\begin{array}{l}\text { Istenič et } \\
\text { al. } 2012\end{array}$ & n.a. & n.a. & n.a. & $<0.5$ & n.a. & $17-80$ & 4-3293 & n.a. & $10-42$ & $<2-220$ & n.a. & n.a. & $26-1361$ \\
\hline
\end{tabular}




\begin{tabular}{|l|l|l|l|l|l|l|l|l|l|l|l|l|l|}
\hline $\mathbf{N = 3}$ & & & & & & & & & & \\
\hline $\begin{array}{l}\text { Jang et } \\
\text { al. 2010 } \\
\mathbf{N = 2 2}\end{array}$ & $<0.8$ & $\begin{array}{l}0.6- \\
24.8\end{array}$ & $\begin{array}{l}8.1- \\
1019\end{array}$ & $\begin{array}{l}<0.37 \\
15 t-5.3\end{array}$ & n.a. & $\begin{array}{l}5.8- \\
174.5\end{array}$ & $4.5-90.4$ & $<0.02$ & $\begin{array}{l}5.4- \\
40.4\end{array}$ & $5.6-196$ & n.a. & n.a. & $5.4-711$ \\
\hline $\begin{array}{l}\text { Färm et } \\
\text { al. 2003 } \\
\text { N=3 }\end{array}$ & $0.314-1.70$ & $\begin{array}{l}10.2- \\
20.7\end{array}$ & n.a. & $1.15-2.93$ & $\begin{array}{l}19.6- \\
34.7\end{array}$ & $\begin{array}{l}51.0- \\
75.7\end{array}$ & $106-159$ & $\begin{array}{l}\text { Kan } \\
\text { finnas }\end{array}$ & $\begin{array}{l}32.0- \\
50.5\end{array}$ & $\begin{array}{l}61.4- \\
98.2\end{array}$ & n.a. & $73.2-106$ & $609-974$ \\
\hline
\end{tabular}

${ }^{1}$ wetlands

${ }^{2}$ stormwater outlets

${ }^{3}$ road residues from stormwater systems

${ }^{4}$ sediment from stormwater tunnels 
275 The sediment depth measurements in different ponds showed that there were no significant 276 differences in sediment depth between the areas surrounding the inlets and outlets (Fig. 1). The largest sediment depths were observed in one of the older ponds (B). Accumulation of material had already occurred at the inlets in one of the newer ponds $(E)$, while the accumulation was still low in the other new pond (C).

The particle size distribution and the sediments varied between sampling sites across individual ponds and between ponds (Fig. 4, all data shown in Supplementary Data Table S2). Most of the sampling sites contained mainly fine material (PSsilt/clay), except for pond E. During sampling in August 2019, erosion of material from the surrounding step banks into the ponds was observed, and thus the sediment may constitute material from both the catchment and the areas directly surrounding the ponds.

A well-designed pond should accumulate coarse material at the inlets and fine material at the outlets, but we observed mixed results. Here, the stormwater ponds were constructed to prevent flooding downstream and have several inlets (e.g. B and E) or several outlets (e.g. D), therefore the hydraulic efficiency may be low. However, previous studies also reported varied results which suggested that fine sediment may also accumulate preferentially at inlets in ponds with high hydraulic efficiency (Istenič et al. 2012; Blecken et al. 2017).

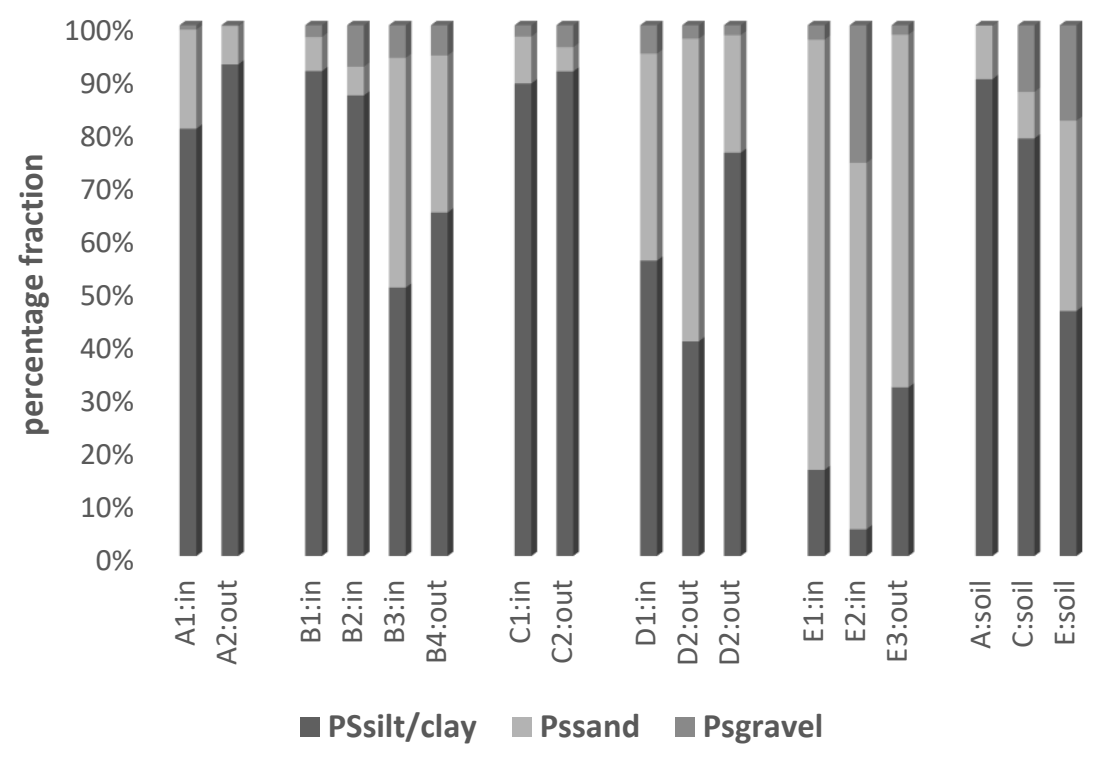

Fig. 4 Particle size distribution of the sediment in the different sampling sites in five stormwater ponds. 
295

296

297

298

299

300

301

302

303

304

305

306

307

308

309

310

311

312

313

314

315

Trends in variation and the relationship between measured variables were further explored using PCA and classification methods. PCA on all element concentration data and sediment characteristics was not possible because the correlation matrix became singular indicating that the data could be replicated as the linear combination of fewer variables. Therefore, PCA was conducted with the element concentration and PSsilt/clay data (Fig. 5). In Fig. 5a the PCA for the 2 first Principle Components is presented for the samples including the soil samples (cases $n=17$ ), the 12 trace elements detected, $\mathrm{P}, \mathrm{S}$ and the silt/clay fraction (variables $\mathrm{n}=15$ ). Only $2 \mathrm{PCs}$ had an eigenvalue above 1 and PC1 and PC2 describe $65.44 \%$ and $24.12 \%$ of the variation respectively. Two distinct groups of variables were identified (Fig. 5a). The first group (Fig 5b), hereafter labelled Group A, consisted of elements with a high negative loading (score) on PC1 include (in descending order) Pb, Cd, Ba, As, Sb, $\mathrm{P}, \mathrm{Zn}, \mathrm{Ag}, \mathrm{Cu}$ and $\mathrm{S}$. They also all have a low positive loading on PC2 except for Ba. The second group, hereafter labelled B (Fig. 5c), consisted of elements and parameters with lower negative loadings on PC1 and higher negative loadings on PC2 included (in descending order of PC 1) V, Cr, PSsilt/clay (i.e. PS $<63 \mu \mathrm{m}$ ) and Ni. Co was included in the second group, but we remark that it showed a very low negative loading on PC1.

The projection of the cases on PC1 and PC2 showed that samples from a given pond were loosely grouped (Fig. 5 d). This suggested that samples taken from a single pond were more similar to each other than to those from other ponds, which reflects differences in catchment characteristics. Samples with the highest contamination level had the highest negative loading in PC1 (i.e. located furthest to the left in Fig. 5b), which indicated that pond B was the most contaminated and pond $E$ was the least contaminated.

A Pearson's $r$ correlation analysis was also conducted to identify correlations between the elements and the sediment characteristics including PSclay/silt (i.e. PS $<63 \mu \mathrm{m}$ ), PSsand (i.e. PS $0.63 \mu \mathrm{m}-2 \mathrm{~mm}$ ), PSgravel (i.e. PS > 2 mm), PScoarse material (i.e. PSsand and PSgravel) and sediment depth (Table 6). Statistically significant positive correlations ( $p \leq 0.05$ ) were observed for PSclay/silt and (in order of decreasing correlation) $\mathrm{V}, \mathrm{Cr} \mathrm{Ni}, \mathrm{S}, \mathrm{Ba}$ and $\mathrm{Co}$; where the same elements also showed significant negative correlation with similar amplitude with PSsand. No significant correlation between PSgravel and the elements was observed. Additionally, (in order of decreasing correlation) P, Pb, Ba, Cd, Sb, Zn, $\mathrm{Ag}$ and $\mathrm{S}$ were significantly correlated with sediment depth. Finally, a correlation analysis was also conducted for the trace elements and the potential indicators of contamination P and S (Table 6). Elements constituting Group A as identified in the PCA (see Fig. 5a,b) showed higher correlation 
327 correlation with S. Group A elements were more strongly correlated with $\mathrm{P}$ than with S.
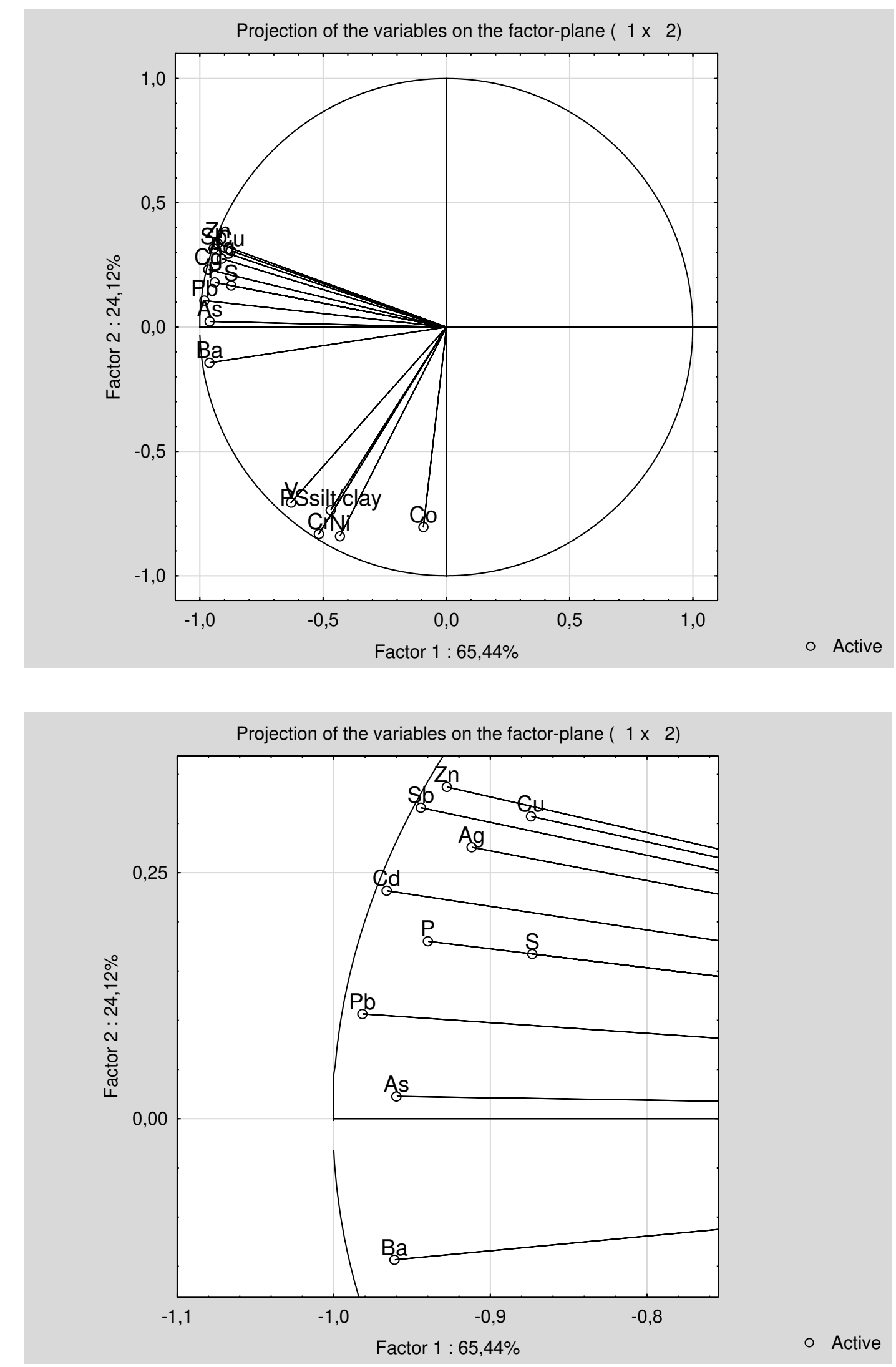

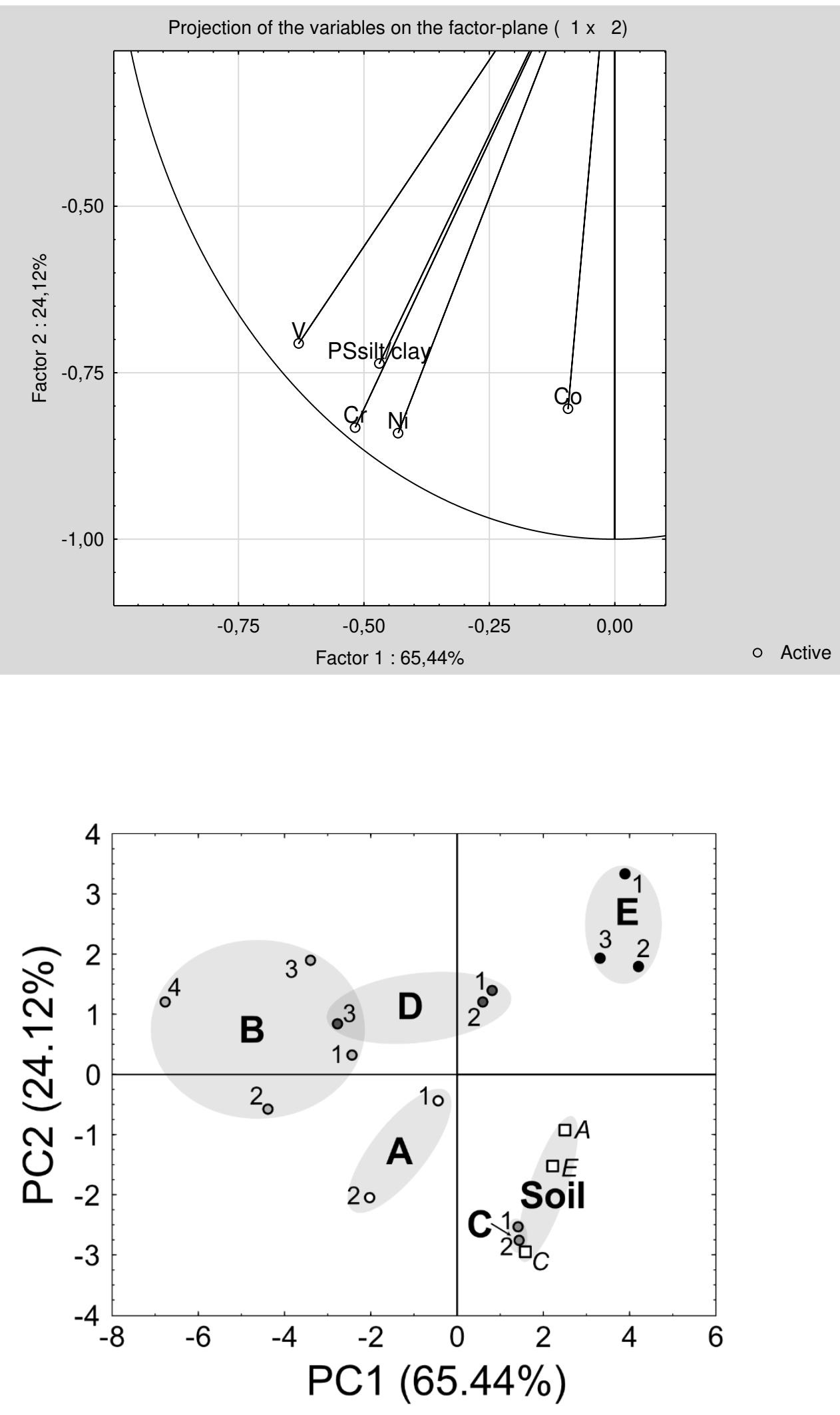

Fig. 5 a) Projection of the variables on PC 1 and PC2. b) Enlarged section of PCA with Group A elements c) Enlarged section of PCA with Group B elements and PSsilt/clay d) Projection of the samples on PC1 and PC2 
Table 6 Pearson $r$ correlations between sediment characteristics and elements. Significant correlations are presented in in bold. Statistical significance was set to $<0.05$

\begin{tabular}{|c|c|c|c|c|c|}
\hline $\begin{array}{l}\text { Element } \\
\mathrm{mg} / \mathrm{kg} \mathrm{DW}\end{array}$ & $\begin{array}{l}\text { PSsilt/clay }{ }^{1} \\
\text { (\%) }\end{array}$ & $\begin{array}{l}\text { PSsand }{ }^{2} \\
\text { (\%) }\end{array}$ & $\begin{array}{l}\text { Sediment } \\
\text { depth } \\
\text { (cm) }\end{array}$ & $\begin{array}{l}\mathrm{P} \\
\mathrm{mg} / \mathrm{kg} \mathrm{DW}\end{array}$ & $\begin{array}{l}\mathrm{S} \\
\mathrm{mg} / \mathrm{kg} \mathrm{DW}\end{array}$ \\
\hline $\mathbf{A g}$ & 0.29 & -0.31 & 0.57 & 0.96 & 0.78 \\
\hline As & 0.48 & -0.47 & 0.53 & 0.90 & 0.82 \\
\hline $\mathrm{Ba}$ & 0.58 & -0.59 & 0.60 & 0.91 & 0.87 \\
\hline Cd & 0.38 & -0.38 & 0.59 & 0.93 & 0.86 \\
\hline Co & 0.54 & -0.68 & 0.16 & 0.10 & 0.15 \\
\hline $\mathrm{Cr}$ & 0.91 & -0.92 & 0.16 & 0.46 & 0.59 \\
\hline $\mathrm{Cu}$ & 0.28 & -0.28 & 0.48 & 0.76 & 0.75 \\
\hline $\mathrm{Ni}$ & 0.85 & -0.86 & 0.14 & 0.42 & 0.47 \\
\hline $\mathbf{P}$ & 0.38 & -0.40 & 0.62 & ------- & 0.84 \\
\hline $\mathrm{Pb}$ & 0.44 & -0.44 & 0.61 & 0.96 & 0.86 \\
\hline $\mathbf{S}$ & 0.59 & -0.58 & 0.54 & 0.84 & ------ \\
\hline Sb & 0.31 & -0.31 & 0.59 & 0.92 & 0.84 \\
\hline v & 0.93 & -0.92 & 0.16 & 0.49 & 0.70 \\
\hline $\mathrm{Zn}$ & 0.26 & -0.26 & 0.58 & 0.89 & 0.80 \\
\hline
\end{tabular}

${ }^{1}$ Particle size $<0.063 \mathrm{~mm}$

338 2Particle size $0.063 \mathrm{~mm}-2 \mathrm{~mm}$

Contamination degree using the geoaccumulation index Igeo $_{\text {g }}$

341 The single element index, $I_{g e o}$ was used to assess the degree of contamination in the sediment. The

342 mean $I_{\text {geo }}$ values for the elements $\mathrm{Co}, \mathrm{Cr}, \mathrm{Ni}$ and $\mathrm{V}$ in all ponds were all negative and the sediment were

343 therefore classified as unpolluted (Class 0 ) with respect to these elements. The mean Igeo for Ba only 344 exceeded 0 in pond $\mathrm{B}(0.3 \pm 0.3)$. The $I_{\text {geo }}$ for the elements $\mathrm{Ag}, \mathrm{As}, \mathrm{Cd}, \mathrm{Cu}, \mathrm{P}, \mathrm{Pb}, \mathrm{S}, \mathrm{Sb}$ and $\mathrm{Zn}$ are shown 345 for each pond in Fig. 6. The complete data set for $I_{g e o}$ values is shown in Supplementary Data Table S3.

346 The highest mean $I_{g e o}$ values were obtained for $\mathrm{Ag}, \mathrm{S}, \mathrm{Sb}$ and $\mathrm{Zn}$. The older ponds (A, B and D) showed 347 higher contamination degree than the newest ponds ( $C$ and $E$ ). Overall, Pond $B$ was the most polluted, 348 showing the highest $I_{\text {geo }}$ values for $\mathrm{Ag}$ (Class 4), S (Class 4 ) and $\mathrm{Sb}$ (Class 6 ) and $\mathrm{Zn}$ (Class 3). Ponds $\mathrm{C}$ and 349 E only showed contamination by $\mathrm{S}$ and $\mathrm{Sb}$ (both ponds) and $\mathrm{Zn}$ (pond $\mathrm{E}$ only). 
Pond A

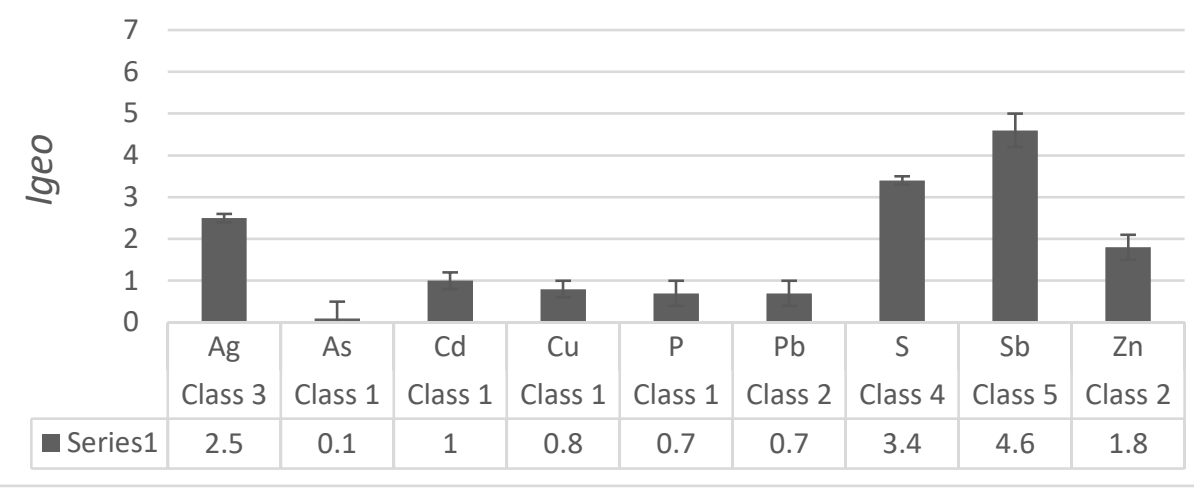

351

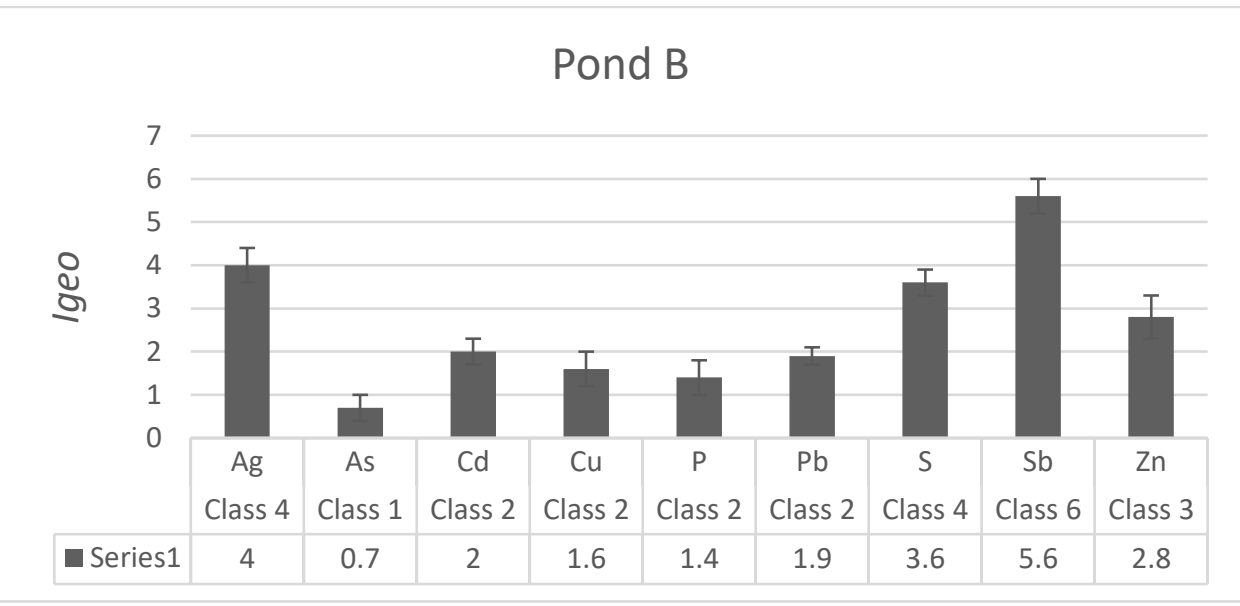

\section{Pond C}

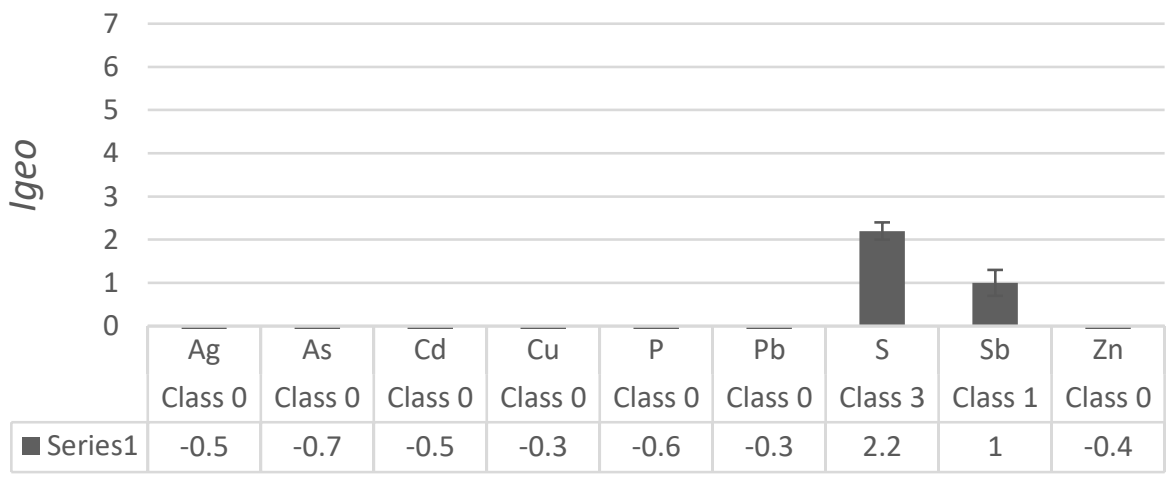



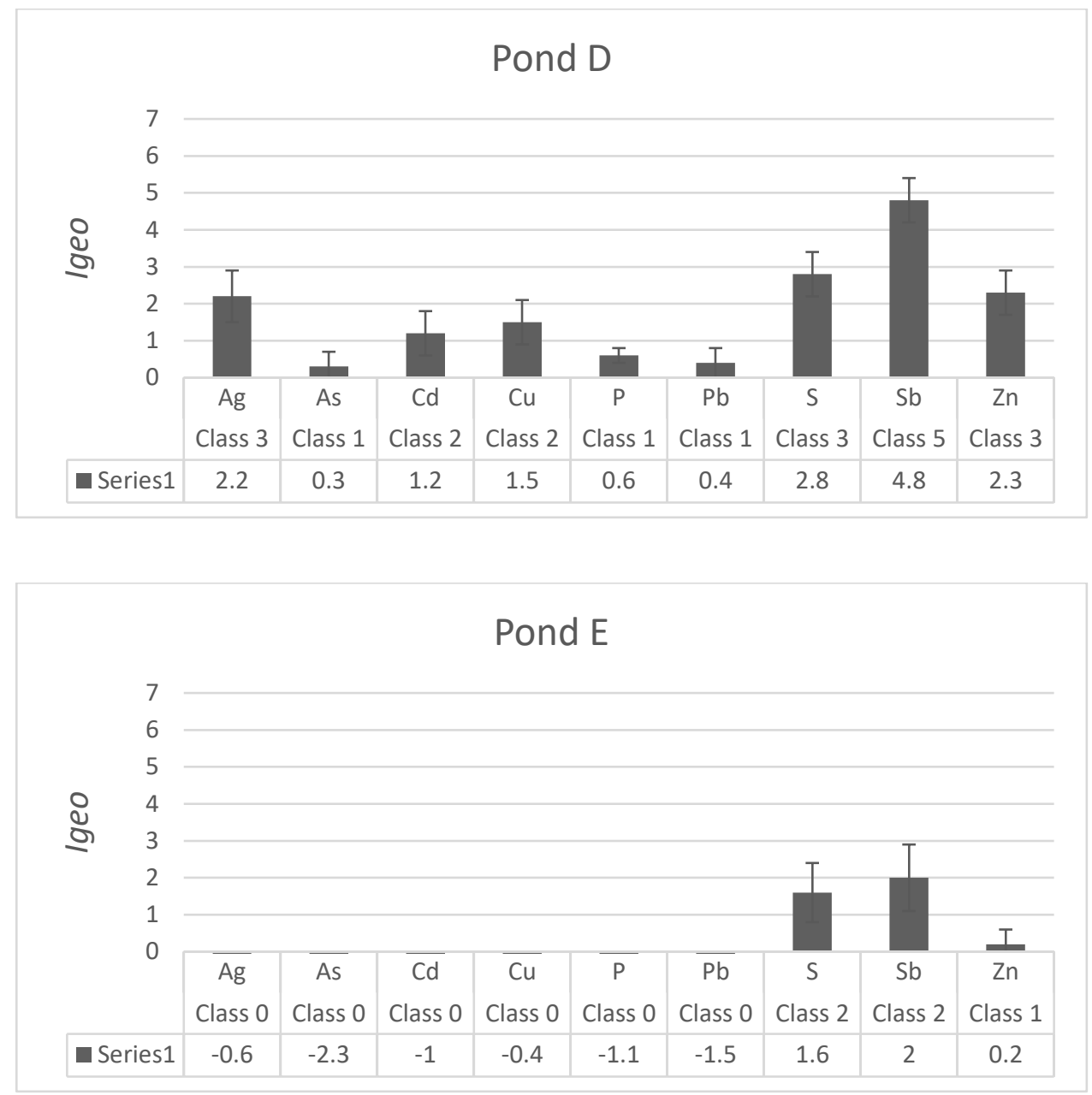

Fig. 6 Contamination degree for trace elements in the different ponds using the geoaccumulation index $I_{\text {geo }}$. Classification was made using mean values, and error bars present standard deviation

\section{Ecological risk assessment using the Potential Ecological Risk Index (RI)}

The mean risk factor, $\mathrm{Er}$, for the elements $\mathrm{As}, \mathrm{Ba}, \mathrm{Co}, \mathrm{Cr}, \mathrm{Cu}, \mathrm{Ni}, \mathrm{Pb}, \mathrm{V}$ and $\mathrm{Zn}$ was below 40 which suggested they provided low potential ecological risk. The $\mathrm{Er}$ values for $\mathrm{Ag}, \mathrm{Cd}$ and $\mathrm{Sb}$ are shown in Table 7, and all data are summarised in Supplementary Data Table S4. Low risk factors $(E r<40)$ were obtained for the newer ponds $C$ and $E$ while the older ponds $A, B$ and $D$ showed very high risks $(E r \geq$ 320) for Ag and Sb.

The RI for ponds $C$ and $E$ were classified as low while the classifications for RI for ponds $A, B$ and $D$ ranged from considerable ecological risk (Class 3 ) to very high ecological risk (Class 4). The highest RI was obtained in pond $B$. 
Table 7 Mean risk factor, $E r$, values for $\mathrm{Ag}, \mathrm{Cd}$ and $\mathrm{Sb}$ with standard deviation; the RI for the sum of risk factors and the contribution, in percentage, of $\mathrm{Ag}, \mathrm{Cd}$ and $\mathrm{Sb}$ to the $\mathrm{RI}$ in sediment from the five stormwater ponds

\begin{tabular}{|c|c|c|c|c|c|c|c|c|}
\hline Pond & $E r-\mathrm{Ag}^{1}$ & $E r-C^{1}$ & $E r-S^{1} b^{1}$ & $\mathrm{RI}^{2}$ & $\begin{array}{l}\% \mathrm{Ag} \text { of } \\
\mathrm{RI}\end{array}$ & $\begin{array}{l}\text { \% Cd of } \\
\text { RI }\end{array}$ & $\begin{array}{l}\text { \% Sb of } \\
\text { RI }\end{array}$ & $\begin{array}{l}\% \\
\mathrm{Ag}+\mathrm{Cd}+\mathrm{Sb} \\
\text { of } \mathrm{RI}\end{array}$ \\
\hline \multirow[t]{2}{*}{ A } & $147 \pm 11$ & $93 \pm 16$ & $267 \pm 75$ & 593 & 25 & 16 & 45 & 86 \\
\hline & Class 3 & Class 3 & Class 4 & Class 3 & & & & \\
\hline \multirow[t]{2}{*}{ B } & $421 \pm 102$ & $182 \pm 44$ & $528 \pm 143$ & 1248 & 34 & 15 & 42 & 91 \\
\hline & Class 5 & Class 4 & Class 5 & Class 4 & & & & \\
\hline \multirow[t]{2}{*}{ C } & $18 \pm 2$ & $31 \pm 0$ & $22 \pm 4$ & 134 & 14 & 23 & 16 & 53 \\
\hline & Class 1 & Class 1 & Class 1 & Class 1 & & & & \\
\hline \multirow[t]{2}{*}{ D } & $129 \pm 66$ & $111 \pm 54$ & $321 \pm 150$ & 646 & 20 & 17 & 50 & 86 \\
\hline & Class 3 & Class 3 & Class 5 & Class 4 & & & & \\
\hline \multirow[t]{2}{*}{$\mathbf{E}$} & $17 \pm 3$ & $25 \pm 12$ & $48 \pm 27$ & 117 & 16 & 20 & 39 & 75 \\
\hline & Class 1 & Class 1 & Class 2 & Class 1 & & & & \\
\hline
\end{tabular}

${ }^{1}$ The risk of single element was classified as according to Håkanson (1980) and here, for convenience, it has been given a numeric classification: Class 1 Low potential ecological risk $E r<40$; Class 2 Moderate potential ecological risk $40 \leq E r<80$, Class 3 Considerable ecological risk $80 \leq E r<160$; Class 4 High potential ecological risk $160 \leq E r<320$ and Class 5 Very high ecological risk $E r>320$.

2 The RI, the sum of the risk factors, was classified according to Håkanson (1980) and here, for convenience, it has been given a numeric classification: Class 1 Low ecological risk RI < 150; Class 2 Moderate ecological risk $150 \leq \mathrm{RI}<300$; Class 3 Considerable ecological risk $300 \leq \mathrm{RI}<600$; Class 4 Very high ecological risk $\mathrm{RI} \geq 600$.

\section{Ecological risk assessment using the RCR-method}

Elements with mean RCRs exceeding 1 in at least one sample are summarised in Table 8, while all data is presented in Supplementary Data Table S5. Mean RCRs in soil were $<1$ for all elements except for $\mathrm{Co}$ and $\mathrm{V}$. In pond sediment mean $\mathrm{RCRs}$ for $\mathrm{Ag}, \mathrm{As}, \mathrm{Cd}, \mathrm{Cr}, \mathrm{Pb}$ were always $\leq 1$. For $\mathrm{Ba}$, two samples (B2 and $\mathrm{B} 4$ ) had a $\mathrm{RCR} \geq 1$ (1.0 and 1.2, respectively). For $\mathrm{Cd}$ and $\mathrm{Ni}$, only samples $\mathrm{B} 4$ and $\mathrm{C} 1$ had a RCR $\geq 1$ (both 1.0). For Co and $V$ all ponds except pond $E$ had a mean RCRs of $2>R C R \geq 1$. Finally, mean RCRs for $\mathrm{Cu}, \mathrm{Sb}$ and $\mathrm{Zn}$ exceeded 2 in numerous samples, where the highest mean RCRs for $\mathrm{Zn}$ (5.6), Sb (2.8) and $\mathrm{Cu}(2.4)$ - and therefore the highest Sum-RCR - was obtained in pond B. The lowest sum-RCR values were obtained for the newest ponds C and E. Indeed, the sum-RCR for the surrounding soil exceeded that of pond $\mathrm{E}$. 
395

396

397

398

399

400

401

402

403

404

405

406

407

408

409

410

411

412

413

414

415

416

417

Table 8 Mean Risk Characterisation Ratio (RCR) with standard deviation for elements measured in soil and sediments in five stormwater ponds. Negligible concentrations (NC, in $\mathrm{mg} / \mathrm{kg}$ DW sediment) was collected from Crommentuijn et al. (2000). Mean RCRs in bold text $\geq 1$, ponds with a at least 1 sample with a RCR $\geq 1$ in italics.

\begin{tabular}{cccccccccc}
\hline Pond & $\mathrm{Ba}$ & $\mathrm{Cd}$ & $\mathrm{Co}$ & $\mathrm{Cu}$ & $\mathrm{Ni}$ & $\mathrm{Sb}$ & $\mathrm{V}$ & $\mathrm{Zn}$ & Sum- \\
& $(157)^{1}$ & $(1.1)$ & $(9.1)$ & $(36)$ & $(35)$ & $(3.2)$ & $(42)$ & $(145)$ & $\mathrm{RCR}^{2}$
\end{tabular}

\begin{tabular}{|c|c|c|c|c|c|c|c|c|c|}
\hline A & $0.8 \pm 0.2$ & $0.4 \pm 0.1$ & $1.2 \pm 0.2$ & $1.3 \pm 0.2$ & $0.7 \pm 0.1$ & $1.4 \pm 0.4$ & $1.6 \pm 0.3$ & $2.7 \pm 0.5$ & $11.1 \pm 2.1$ \\
\hline B & $1.0 \pm 0.2$ & $0.8 \pm 0.2$ & $1.1 \pm 0.2$ & $2.4 \pm 0.7$ & $0.7 \pm 0.2$ & $2.8 \pm 0.8$ & $1.3 \pm 0.2$ & $5.6 \pm 1.9$ & $17.3 \pm 4.2$ \\
\hline C & $5 \pm 0.0$ & $1 \pm 0.0$ & $1.4 \pm 0.0$ & $6 \pm 0.0$ & $1.0 \pm 0.0$ & $0.1 \pm 0.0$ & $1.3 \pm 0.1$ & $0.6 \pm 0.1$ & $6.3 \pm 0.1$ \\
\hline D & $0.6 \pm 0.1$ & $0.5 \pm 0.2$ & $1.0 \pm 0.2$ & & $0.5 \pm 0.1$ & & & & $12.3 \pm 4.5$ \\
\hline$E$ & $0.3 \pm 0.1$ & $0.1 \pm 0.1$ & $0.8 \pm 0.5$ & $0.6 \pm 0.1$ & $0.3 \pm 0.1$ & $0.3 \pm 0.1$ & $0.5 \pm 0.2$ & $0.9 \pm 0.2$ & $3.9 \pm 0.4$ \\
\hline soil & $0.5 \pm 0.1$ & $0.1 \pm 0.0$ & $1.4 \pm 0.3$ & $0.5 \pm 0.0$ & $0.8 \pm 0.2$ & $0.0 \pm 0.0$ & $1.1 \pm 0.1$ & $0.5 \pm 0.0$ & $5.6 \pm 0.8$ \\
\hline
\end{tabular}

${ }^{1} \mathrm{NC}$ in parenthesis

${ }^{2}$ sum mean RCR for all elements analysed except $P$ and $S$

\section{Remediation requirements}

The complete data set is shown in Supplementary Data Table S2. The mean concentration of each element in background soil was below the respective generic guideline values for both less sensitive land use (MKM) and sensitive land use (KM). The KM value for Co was, however, exceeded in the surrounding soil from pond $C$. The generic guideline value for less sensitive land use (MKM) was never exceeded in pond sediments except for $\mathrm{Zn}$ where all samples from pond $\mathrm{B}$ exceeded the MKM value as did the sample D3 from pond D. Based upon means the KM value was exceeded in pond $A$ for $Z n$, for pond $\mathrm{B}$ for $\mathrm{As}, \mathrm{Cd}, \mathrm{Cu}, \mathrm{Pb}$ and $\mathrm{Zn}$ (i.e. exceeds MKM) and for pond $\mathrm{D}$ for $\mathrm{Cu}$ and $\mathrm{Zn}$ (i.e. $\mathrm{Zn}$ exceeds MKM). No sediment concentrations exceeded $K M$ values in pond $C$ and $E$. This suggest that some elements - particularly $\mathrm{Zn}$ - will limit the re-use of the sediments from the older ponds and they may require costly and laborious clean-up procedures (Zubala et al. 2018) when excavated in the future.

\section{Priority ranking of ponds and elements}

The ponds were then ranked according to their $I_{g e o}, \mathrm{RI}$ and RCR values (Table 9). The rankings were similar for all methods except $I_{\text {geo }}$ was higher in pond $\mathrm{E}$ than in pond $\mathrm{C}$. Overall, Pond B was the most contaminated. The degree of contamination was summarised as $B \gg D \approx A>C \approx E$. The degree of contamination in ponds $C$ and $E$ was low such that their RCR values matched those of the surrounding soil. This confirmed that the younger ponds ( $\mathrm{C}$ and $\mathrm{E}$ ) were less contaminated than the older ponds. In theory, the annual accumulation of trace element should be the same if it is not influenced by other factors. In this case, it was assumed that low rainfall during 2018,60\% less than normal (Swedish Meteorological and Hydrological Institute 2021), contributed to a low accumulation. Additionally, the 
percentage impervious surface of pond C was low (12\%) as the pond was constructed before the

419 industrial area has been fully developed.

420

421

422

423

424

425

426

427

428

429

430

431

432

433

434

435

436

437

438

439

440

441

442

443

444

445

446

447

448

449

The 3 ranking methods used were originally developed for sediment quality assessment in lakes and watercourses (Müller 1969; Håkanson 1980; Crommentuijn et al. 2000). To our knowledge, this study represented the first use of $I_{g e o}$ and $\mathrm{RI}$ in the risk assessments of stormwater ponds sediment. The RCRmethod is rarely used but sediment guidelines are frequently compared to measured values when assessing the quality of stormwater sediment (Färm et al. 2003; Andersson et al. 2004; Färm and Waara 2005; Jang et al. 2010; Blecken et al. 2012; Sharley et al. 2017; Crane 2019). It is encouraging that $I_{\text {geo, }}$ for which there is no need to find neither Tr nor PNEC values, provided a similar ranking as the RI and the RCR-method. This suggested that the $I_{g e o}$ method is suitable for evaluating the risk caused by the accumulation of emerging contaminants in stormwater ponds.

Although the different ranking methods indicated somewhat different elements of concern (see Table 9), their scales for classification were different and P and S were not included in the RI and Sum-RCR values. $\mathrm{P}$ and $\mathrm{S}$ are not considered toxic trace elements, but they are used in this study to investigate if they are correlated with the accumulated trace elements. Both elements belong to the Group A elements identified in the PCA (see Fig. 5a,b) and they were significantly correlated with the trace elements with a high $I_{\text {geo }}$ (Fig. 6). P and S are rarely analysed in sediment in stormwater ponds, but the P level measured here was within the same range (358-4130 mg/kg DW) as reported by Istenič et al. 2012 (90-1810 mg/kg DW). The levels for S found in this study (347-3170 mg/kg DW) are within the lower range of the interval found by Blecken et al. in 2012 (358-16000 mg/kg DW). Finally, while both $\mathrm{P}$ and $\mathrm{S}$ showed high and significant correlation coefficients with trace elements with a high $I_{g e o}, \mathrm{P}$ showed very low accumulation compared to $\mathrm{S}$. This indicated that $\mathrm{S}$ was generally a better indicator of contamination than $\mathrm{P}$, but additional studies are necessary to explore if $\mathrm{S}$ content can be a general indicator of pollution in stormwater ponds.

It was assumed that the RCR values for $\mathrm{Co}, \mathrm{Ni}$ and $\mathrm{V}(>1)$ were questionable since $I_{\text {geo }}$ indicated no accumulation of these elements above the background reference soil (Table 9). The NC value used as PNEC was derived for risk assessments made in the Netherlands, which accounted for higher local background concentrations than what we observed in own reference soil (except Co and V; Crommentuijn et al. 2000). There are currently no available environmental quality standard (EQS) for sediment in lakes and watercourses in Sweden for most of the trace elements analysed, except for Cd $(\mathrm{EQS}=2.3 \mathrm{mg} / \mathrm{kg} \mathrm{DW}, \mathrm{NC}=1.1 \mathrm{mg} / \mathrm{kg} \mathrm{DW}), \mathrm{Cu}(\mathrm{EQS}=36 \mathrm{mg} / \mathrm{kg} \mathrm{DW}, \mathrm{NC}=37 \mathrm{mg} / \mathrm{kg} \mathrm{DW})$ and Pb (EQS=130 mg/kg DW, NC = $132 \mathrm{~m} / \mathrm{kg}$ DW) (HVMFS2019:25). However, replacing the NCs used in this 
study with the national EQSs only marginally changed the RCRs for $\mathrm{Cu}$ and $\mathrm{Pb}$, although the average $\mathrm{RCR}$ for $\mathrm{Cd}$ fell under 1 . As both the $I_{g e o}$ and $E r$ values indicated that $\mathrm{Cd}$ was an element of concern in pond $\mathrm{B}, \mathrm{Cd}$ was kept as an element of concern overall. Denmark has set a national guideline for $\mathrm{V}$ to $23.6 \mathrm{mg} / \mathrm{kg}$ DW using the added risk approach (Ministry of Environment and Food of Denmark. 2017), which can be added to the background concentration. In our case, the concentration in a sample must have exceeded $71.7 \mathrm{mg} / \mathrm{kg} \mathrm{DW}$ (i.e. $48.1+23.6=71.7$ ) to affect the ecosystem negatively, and this level was only exceeded in sample A2 (Supplementary Data Table S2).

The NCs and the national EQSs for $\mathrm{Cd}, \mathrm{Cu}$ and $\mathrm{Pb}$ were calculated under the assumption that the total organic carbon (TOC) was $5 \%$, and that at a higher TOC the trace elements would bind to the organic matter and become biologically unavailable (CIS 2011). Organic $C$ was not measured in this study, but we assume that organic $\mathrm{C}$ content would vary depending upon land use and amount of vegetation in the ponds.

$\mathrm{Ag}$ is considered an element of concern despite low RCR levels (i.e. $\mathrm{RCR}<1$ ) because the $I_{\text {geo }}$ value indicated extensive accumulation and the $\mathrm{Er}$ value was high. $\mathrm{Cu}$ was also classified as an element of concern even though the RCR was also below 1 because the $I_{\text {geo }}$ and Er value indicated a risk and the $\mathrm{KM}$ guideline was exceeded in pond $\mathrm{B}$ and $\mathrm{D}$. $\mathrm{As}$ and $\mathrm{Pb}$ are interesting cases as the $I_{\text {geo }}$ indicated accumulation in pond $A, B$ and $D$ and the RCRs were below 1 , but the $K M$ values for $P b(K M=50 \mathrm{mg} / \mathrm{kg}$ $D W ; N C=132 \mathrm{mg} / \mathrm{kg} \mathrm{DW})$ and $A s(K M=10 \mathrm{mg} / \mathrm{kg} \mathrm{DW} ; \mathrm{NC}=31 \mathrm{mg} / \mathrm{kg} \mathrm{DW})$ were exceeded in pond $\mathrm{B}$. This was attributed to the setting of the generic guideline values for contaminated soil for both ecological and human risk. The RCR for Ba was above 1 only in pond B, while Igeo indicated only slight pollution (Class 1 ) and the Er value indicated low risk in the same pond. Consequently, Ba may not be classified as an element of concern. The high RCRs in pond A, B and D for Sb and Zn agreed directly with the $I_{g e o}$ and $E r$ classification and were thereby classed as elements of high concern. $\mathrm{Sb}$ and $\mathrm{Zn}$ also show high correlation in the PCA (Fig. 5b) and may therefore have a common source of origin. In conclusion, the use and comparison of three risk assessment methods confirmed that both commonly monitored trace elements $(\mathrm{Cd}, \mathrm{Cu}, \mathrm{Zn})$ and seldom monitored trace elements $(\mathrm{Ag}, \mathrm{Sb})$ may cause an ecological risk in the ponds.

For Ag (Färm et al. 2003; Frost et al. 2015; Sharley et al. 2017; Crane 2019) and Sb (Sharley et al. 2017; Crane 2019) we have found only a few records of measurements in stormwater ponds with catchments featuring industrial land yet the current data showed that the monitoring these elements is paramount as they showed very high accumulation compared to the background. Ag is currently used in many nanomaterials in textiles, medical products, food containers, cosmetics, paints and nano- 
functionalised plastics (McGillicuddy et al. 2017). Meanwhile, Sb is used in catalysts for production of

483 polyethylene terephthalate (PET), and in flame retardants for various materials such as paper, plastic, 484 paints and textiles (Wang et al. 2018); and brake linings (Wang et al. 2018, Müller et al. 2020). It has 485 recently been found in high concentration in plastic waste fractions (Viczek et al. 2020); and shown to 486 be mobilised from microplastic in coastal estuarine sediments when extracted with fluids that simulate the digestive system of sediment dwelling invertebrates (James and Turner 2020). Significantly, Pond $D$ is located near to a municipal recycling plant. As the industrial areas are less than $5 \mathrm{~km}$ apart, they may also experience similar sources of local and long-distance transport of airborne pollutants. Clearly, further studies are needed to determine whether the high accumulation of $\mathrm{Ag}$ and $\mathrm{Sb}$ in the studied stormwater ponds is a local phenomenon or not.

In this study, the total amount of certain elements was measured and risk-assessed. There are several studies that indicate that heavy metals preferentially accumulate in the roots of macrophytes and are therefore unlikely to become bioavailable via plant uptake and translocation (Istenič et al. 2012). Benthic organisms have also been shown to accumulate heavy metals in stormwater ponds such as $\mathrm{Cd}$, $\mathrm{Cr}, \mathrm{Ni}$ and $\mathrm{Cu}$ (Stephansen et al. 2014), but they might not reach toxic levels as was demonstrated by Andersson et al. (2004) and Casey et al. (2006). Recently, Sun et al. (2019) studied the biodiversity in roadside ponds and found that most of the taxa displayed in the ordination diagram were negatively correlated with the pollution levels in the water column and sediments, while a positive correlation with the pond size and the number of neighbouring ponds was observed. Whether the trace elements studied here will cause toxicity and thereby reduce the biodiversity in catchments with industrial activity remains to be explored. 
Table 9 Priority ranking of contamination in the ponds and identified elements of concern based upon $I_{\text {geo, }} \mathrm{RI}$ and RCR

\begin{tabular}{|c|c|c|c|c|c|c|c|}
\hline Pond & $\begin{array}{l}\text { Rank } \\
\text { Sum- } \\
I_{\text {geo }}{ }^{1} \\
\end{array}$ & $\begin{array}{l}\text { Rank } \\
\mathbf{R I}^{2}\end{array}$ & $\begin{array}{l}\text { Rank } \\
\text { Sum- } \\
\text { RCR }^{3} \\
\end{array}$ & Rank $^{4}$ & $I_{g e o} 5$ & $\begin{array}{l}\text { mean- } \\
E r>40^{6}\end{array}$ & mean-RCR $\geq 1^{7}$ \\
\hline & \multicolumn{4}{|c|}{ Ranking of ponds } & \multicolumn{3}{|c|}{ Elements of concern } \\
\hline A & $3(11.8)$ & $3(593)$ & $3(11.1)$ & 3 & $\mathrm{Ag}, \mathrm{S}, \mathrm{Sb}, \mathrm{Zn}$ & $\mathrm{Ag}, \mathrm{Cd}, \mathrm{Sb}$ & $\mathrm{Cu}, \mathrm{Sb}, \mathrm{V}, \mathrm{Zn}$ \\
\hline B & $1(18.5)$ & $1(1248)$ & $1(17.3)$ & 1 & $\begin{array}{l}\mathrm{Ag}, \mathrm{Cd}, \mathrm{Cu}, \\
\mathrm{P}, \mathrm{Pb}, \mathrm{S}, \mathrm{Sb}, \\
\mathrm{Zn}\end{array}$ & $\mathrm{Ag}, \mathrm{Cd}, \mathrm{Sb}$ & $\begin{array}{l}\mathrm{Ba}, \mathrm{Cd}^{8}, \mathrm{Co}, \mathrm{Cu}, \\
\mathrm{Sb}, \mathrm{V}, \mathrm{Zn}\end{array}$ \\
\hline C & $5(1.0)$ & $4(134)$ & $4(6.3)$ & 4 & S & None & Co, $\mathrm{Ni}, \mathrm{V}$, \\
\hline D & $2(12.6)$ & $2(646)$ & $2(12.3)$ & 2 & $\begin{array}{l}\mathrm{Ag}, \mathrm{Cd}, \mathrm{Cu}, \\
\mathbf{S}, \mathbf{S b}, \mathbf{Z n}\end{array}$ & $\mathrm{Ag}, \mathrm{Cd}, \mathrm{Sb}$ & $\mathrm{Co}, \mathrm{Cu}, \mathrm{Sb}, \mathrm{V}, \mathrm{Zn}$ \\
\hline $\mathbf{E}$ & $4(2.1)$ & $5(117)$ & $5(3.9)$ & 5 & $\mathrm{~S}, \mathrm{Sb}$ & $\mathrm{Sb}$ & none \\
\hline $\begin{array}{l}\text { soil } \\
\text { List el }\end{array}$ & $\begin{array}{l}\text { n.a. } \\
\text { nents of }\end{array}$ & $\begin{array}{l}\text { n.a. } \\
\text { ncern }\end{array}$ & 5.6 & n.a. & $\begin{array}{l}\text { n.a. } \\
\mathrm{Ag}, \mathrm{Cd}, \mathrm{Cu},(\mathrm{P}\end{array}$ & $\begin{array}{l}\text { n.a. } \\
\text { b), Sb, Zn }\end{array}$ & Co, V \\
\hline
\end{tabular}

${ }^{1}$ Sum $I_{\text {geo }}$ in parenthesis, when calculating sum $I_{\text {geo }}$ negative $I_{\text {geo }}$ values have been set to 0 . $I_{\text {geo }}$ was calculated for all elements except $\mathrm{Hg}$ which was below detection limit in all samples. Sum $I_{\text {geo }}$ has been calculated to enable comparison in the risk ranking of the ponds.

${ }^{2}$ Sum Mean Potential Ecological Risk Index in parenthesis, RI was calculate including all elements except $\mathrm{Hg}, \mathrm{P}$ and $\mathrm{S}$, see also Table 7.

${ }^{3}$ Sum Mean RCR in parenthesis, Sum RCR was calculated for all elements except $\mathrm{Hg}, \mathrm{P}$ and S, see also Table 8

${ }^{4}$ Based upon sum of the 3 ranking methods

${ }^{5}$ Mean $I_{\text {geo }}$ values classified in Class 2 or higher are included, values in Class 3 or higher in bold

${ }^{6}$ Mean Er values higher than Class 2 are included, values in bold are Class 3 or higher, see Table 7

${ }^{7}$ mean $\mathrm{RCR}>2$ in bold

${ }^{8}$ for one sampling site (B4) the RCR is above 1

${ }^{9}$ n.a. - not applicable, soil is used in calculation of $I_{\text {geo }}$ and RI

\section{Conclusions}

There is an urgent need to update the list of trace elements that are routinely monitored in sediment in stormwater ponds when evaluating ecological risk, especially in ponds with catchments in areas of industrial land use. The ponds in this study were mainly constructed to protect downstream areas from flooding during high flows and therefore have low hydraulic efficiency. Accordingly, some trace elements that bind to finer particles that did not sediment in the ponds might therefore flow into the river downstream. Currently, there is no information about background concentrations nor the degree of pollution of $\mathrm{Ag}$ and $\mathrm{Sb}$ in the downstream catchment nor in other catchments in the region of study. Therefore, the development of a program for monitoring numerous trace elements - significantly more than what is currently monitored - is essential. Identifying the sources of the high accumulation of $\mathrm{Ag}$ and $\mathrm{Sb}$ found in this study is another priority. Finally, we showed that the use and comparison of different assessment methods including multivariate analyses when evaluating ecological risk of 
533 stormwater pond sediment is valuable as it highlighted different aspects of risk. For example, 534 information from the geoaccumulation index combined with the multivariate analyses clearly 535 demonstrated that $\mathrm{Co}, \mathrm{Ni}$ and $\mathrm{V}$ were not accumulating and therefore their risk as identified by the 536 RCR-method was overestimated. On the other hand, for Ag, RCRs are below 1 also in the most contaminated pond B while the geoaccumulation index and RI indicates high accumulation and high risk, triggering the need for additional studies.

\section{Declarations}

540 Ethics approval and consent to participate: Not applicable

541 Consent for publication: Not applicable

542 Availability of data and materials: All data generated or analysed during this study are included in this 543 published article and its supplementary information files.

544 Competing interests: The authors declare that they have no competing interests.

545 Funding: This study was financially supported by the Municipality of Ängelholm.

546 Authors' contributions: Sylvia Waara: conceptualization, methodology, investigation, analysis and 547 writing, Frida Johansson: writing, investigation and analysis. Both authors read and approved the 548 final manuscript. 


\section{References}

551 Aksu A, Yasar D, Uslu O (1998) Assessment of marine pollution in Izmir Bay: Heavy Metal and Organic 552 Compound Concentrations in Surficial Sediments. Turkish Journal of Engineering and Environmental 553 Sciences 22:387-415.

554

572 Crommentuijn T, Sijm D, de Bruijn, J, van den Hoop M, van Leeuwen K, van de Plassche, E (2000)

573 Maximum permissible and negligible concentrations for metals and metalloids in the Netherlands, 574 taking into account background concentrations. J Environ Manage 60:121-143.

Allen D, Haynes H, Arthur S (2017) Contamination of detained sediment in sustainable urban drainage systems. Water 9:355. https://doi.org/10.3390/w9050355.

Anderson BC, Bell T, Hodson P, Marsalek J, Watt WE (2004) Accumulation of trace metals in freshwater invertebrates in stormwater management facilities. Water Qual Res Canada 39:362-373.

Baekken T (1994) Effects of highway pollutants on a small Norwegian lake. Sci Total Environ 146/147:131 - 139 .

Blecken G-T, Rentz R, Malmgren C, Öhlander B, Viklander M (2012) Stormwater impact on urban waterways in cold climate: variations in sediment metal concentrations due to untreated snowmelt discharge. J Soil Sediments 12:758-773.

Blecken G, Al-Rubaei A, Viklander M, Marsalek J (2017) 25 municipal stormwater management ponds in Sweden - survey of the operational status. Bromma: Svenskt Vatten (In Swedish).

Casey RE, Simon JA, Atueyi S, Snodgrass JW, Karouna-Renier N, Sparling DW (2006) Temporal trends of trace metals in sediment and invertebrates from stormwater management ponds. Water Air Soil Pollut 178:69-77.

CIS (2011) Technical Guidance for Deriving Environmental Quality Standards, Technical report 2011055. Common Implementation Strategy for the Water Framework Directive (2000/60/EC).

Crane JL (2019) Distribution, toxic potential, and influence of land use on conventional and emerging contaminants in urban stormwater pond sediments. Arch Environ Contam Toxicol 76:265-294.

Duodu GO, Goonetilleke A, Ayoko GA (2016) Comparison of pollution indices for the assessment of heavy metal in Brisbane River sediment. Environ Pollut 2019:1077-1091. 
577 ECHA (2016) Guidance on Information Requirements and Chemical Safety Assessment Part E: Risk 578 Characterisation. Version 3.0. May 2016, ISBN 978-92-9495-055-0.

579 Egemose S, Sønderup MJ, Grudinina A, Hansen AS, Flindt MR (2015) Heavy metal composition in 580 stormwater and retention in ponds dependent on pond age, design and catchment type. Environ 581 Technol 36:959-969.

582 European Chemicals Bureau (2003) Technical Guidance Document on Risk Assessment. Part II. 583 Environmental Risk Assessment.

584 Frost PC, Song K, Buttle JM, Marsalek J, McDonald A, Xenopoulos MA (2015) Urban biogeochemistry 585 of trace elements: What can the sediments of stormwater tell us? Urban Ecosyst 18:763-775.

586 Färm C, Johansson D, Kadic Z, Waara S (2003) Characterisation of sediment from storm water tunnels. 587 In: Tiezzi E, Brebbia CA, Usó J-L. (eds) Ecosystem and Sustainable Development, vol 2:1253-1262, WIT 588 Press, Transactions on Ecology and the Environment.

589 Färm C, Waara S (2005) Treatment of stormwater using a detention pond and constructed filters. 590 Urban Water J 2:51-58.

591 HVMFS2019:25. Classification and environmental quality standards for surface water (In Swedish). 592 Swedish Agency for Marine and Water Management.

593 Håkanson L (1980) An ecological risk index for aquatic pollution control: a sedimentological approach. 594 Water Res 14:975-1001.

595 Istenič D, Arias CA, Vollertsen J, Nielsen AH, Wium-Anderson T, Hvitved-Jacobsen T, Brix H (2012) 596 Improved urban stormwater treatment and pollution removal pathways in amended wet detention 597 ponds. J Environ Sci Health A, 47:1466-1477.

598 James E, Turner A (2020) Mobilisation of antimony from microplastics added to coastal sediment. 599 Environ Pollut 264, https://doi.org/10.1016/i.envpol.2020.114696

600 Jang Y-C, Jain P, Tolaymat T, Dubey B, Singh S, Townsend T (2010) Characterization of roadway 601 stormwater system residuals for reuse and disposal options. Sci Total Environ 408:1878-1887. 
602

603

604

605

606

607

608

609

610

611

612

613

614

615

616

617

618

619

620

621

622

623

624

625

626

627

Jefferson AJ, Bhaskar AS, Hopkins KG, Fanelli R, Avellaneda PM, McMillan SK (2017) Stormwater management network effectiveness and implications for urban watershed function: A critical review. Hydrological Processes 31:4056-4080.

Jiao F, Ren L, Wang X, Liu W (2017) Pollution characteristics and potential ecological risk assessment of metals in the sediments of Xiaoqing River, Jinan Environ Sci Pollut Res 24:15001-15011.

Li W, Lin S, Wang W, Huang Z, Zeng H, Chen X, Zeng, F, Fan, Z. (2020) Assessment of nutrient and heavy metal contamination in surface sediments of the Xiashan stream, eastern Guangdong Province, China. Environ. Sci. Pollut. Res. 27:25908-25924.

Maltby L, Forrow DM, Boxall ABA, Calow P, Betton C (1995) The effects of motorway runoff on freshwater ecosystems: 1. Field study. Environ Toxicol Chem 14:1079-1092.

Manoj K, Padhy PK (2014) Distribution, Enrichment and Ecological Risk Assessment of Six Elements in Bed Sediments of a Tropical River, Chottanagpur Plateau: A Spatial and Temporal Appraisal. J Environ Prot 5:1419-1434.

Marsalek J, Urbonas B, Lawrence I (2005) Stormwater management ponds. In: Shilton A (Ed) Pond treatment technology, IWA Publishing, London pp 433-459.

McGillicuddy E, Murray I, Kavanagh S, Morrison L, Fogarty A, Cormican M, Dockery P, Prendergast M, Rowan N, Morris D (2017) Silver nanoparticles in the environment: Sources, detection and ecotoxicology. Sci Total Environ 575:231-246.

Ministry of Environment and Food of Denmark. 2017. Bekendtgørelse af lov om vandplanlægning. LBK nr 126 af 26/01/2017. https://www.retsinformation.dk/Forms/R0710.aspx?id=196701

Müller G (1969) Index of geoaccumulation in the sediments of the Rhine River. Geojournal 2:108-118.

Müller A, Österlund H, Marsalek J, Viklander M. (2020) The pollution conveyed by urban runoff: A review of sources. Sci Total Environ 709, https://doi.org/10.1016/j.scitotenv.2019.136125.

Nika MC, Ntaiou K, Elytis K, Thomaidi VS, Gatidou G, Kalantzi OI, Thomaidis NS, Stasinakis AS (2020) Wide-scope target analysis of emerging contaminants in landfill leachates and risk assessment using Risk Quotient methodology. J of Hazard Mater 394, https://doi.org/10.1016/j.jhazmat.2020.122493. 
628

629

630

631

632

633

634

635

636

637

638

639

640

641

642

643

644

645

646

647

648

649

650

651

652

653

Sharley DJ. Sharp MS, Bourgues S, Pettigrove VJ (2016) Detecting long-term temporal trends in sediment-bound trace metals from urbanised catchments. Environ Pollut 2019:705-713.

Sharley JD, Sharp MS, Marshall S, Jeppe M, Pettigrove JV (2017) Linking urban land use to pollutants in constructed wetlands: Implications for stormwater and urban planning. Landscape and Urban Planning 162:80-91.

Stephansen DA, Nielsen AH, Hvitved-Jacobsen T, Arias CA, Brix H, Vollertsen J (2014) Distribution of metals in fauna, flora and sediments of wet detention ponds and natural shallow lakes. Ecol Eng 66:4351.

Sun Z, Sokolova E, Brittain JE, Saltveit SJ, Rauch S, Meland S (2019) Impact of environmental factors on aquatic biodiversity on roadside ponds. Scientific Reports 9:5994.

Søberg LC, Vollertsen J, Blecken GT, Haaning Nielsen A, Viklander M (2016) Bioaccumulation of heavy metals in two wet retention ponds. Urban Water J 13:697-709.

Swedish Meteorological Institute (SMHI) 2021.

https://www.smhi.se/data/meteorologi/kartor/karta/foregaende-ar/nederbord/

Swedish Environmental Protection Agency (2009) Guideline values for contaminated soil. Model description and guidelines. (In Swedish) Report 5976.

Swedish Environmental protection Agency (2016). Updated list of guideline values. (In Swedish) https://www.naturvardsverket.se/upload/stod-i-miljoarbetet/vagledning/fororenadeomraden/berakning-riktvarden/generella-riktvarden-20160707.pdf

Viczek SA, Aldrian A, Pomberger R, Sarc R (2020) Origins and carriers of Sb, As, Cd, Cl, Cr, Co, Pb, $\mathrm{Hg}$, and $\mathrm{Ni}$ in mixed solid waste - A literature-based evaluation. Waste Manage 103:87-112.

Wang J-Z, Peng S-Ch, Chen T-H, Zhang L (2016) Occurrence, source identification and ecological risk evaluation of metal elements in surface sediment: toward a comprehensive understanding of heavy metal pollution in Chaohu Lake, Eastern China. Environ Sci Pollut Res 23:307-314.

Wang N, Wang A, Kong L, He M (2018) Calculation and application of Sb toxicity coefficient for potential ecological risk assessment. Sci Total Environ 610-611:167-174. 
654 Wei L, Cai M, Du Y, Tang J, Wu Q, Xiao T, Luo D, Huang X, Liu Y, Fei Y, Chen Y. (2019) Spatial Attenuation 655 of Mining/Smelting-Derived Metal Pollution in Sediments from Tributaries of the Upper Han River, 656 China. Mine Water Environ 38:410-420.

657 Yang J, Wang, W, Zhao M, Chen B, Dada OA, Chu Z (2015) Spatial distribution and historical trends of 658 heavy metals in the sediments of petroleum producing regions of the Beibu Gulf, China. Mar Pollut 659 Bull 91:87-95.

660 Zhang H, Jiang Y, Ding M, Xie Z (2017) Level, source identification, and risk analysis of heavy metal in 661 surface sediments from river-lake ecosystems in the Poyang Lake, China. Environ Sci Pollut Res $662 \quad 24: 21902-21916$.

663 Zhou S, Di Paolo C, Wu X, Shao Y, Seiler TB, Hollert H (2019) Optimization of screening-level risk 664 assessment and priority selection of emerging pollutants - The case of pharmaceuticals in European 665 surface waters. Environ Int 128:1-10.

666 Zhu X, Ji H, Chen Y, Qiao M, Tang L (2013) Assessment and sources of heavy metals in surface sediments 667 of Miyun Resorvoir, Beijing. Environ Monit Assess 185:6049-6062. municipal stormwater treatment plant. Environ Sci Pollut Res 24:17145-17152. 
Figures
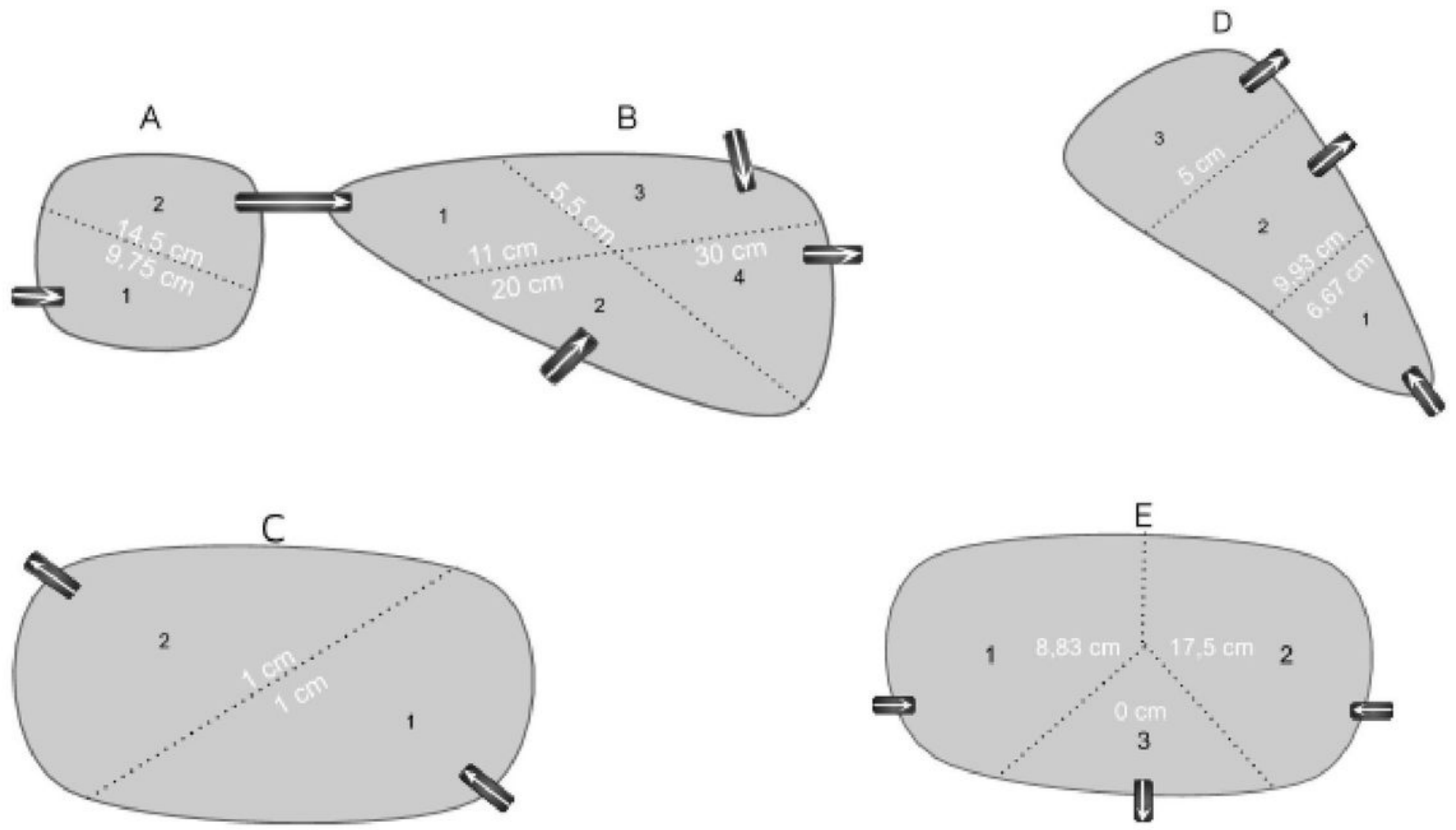

Figure 1

Design of the ponds and the measured thickness of sediment 

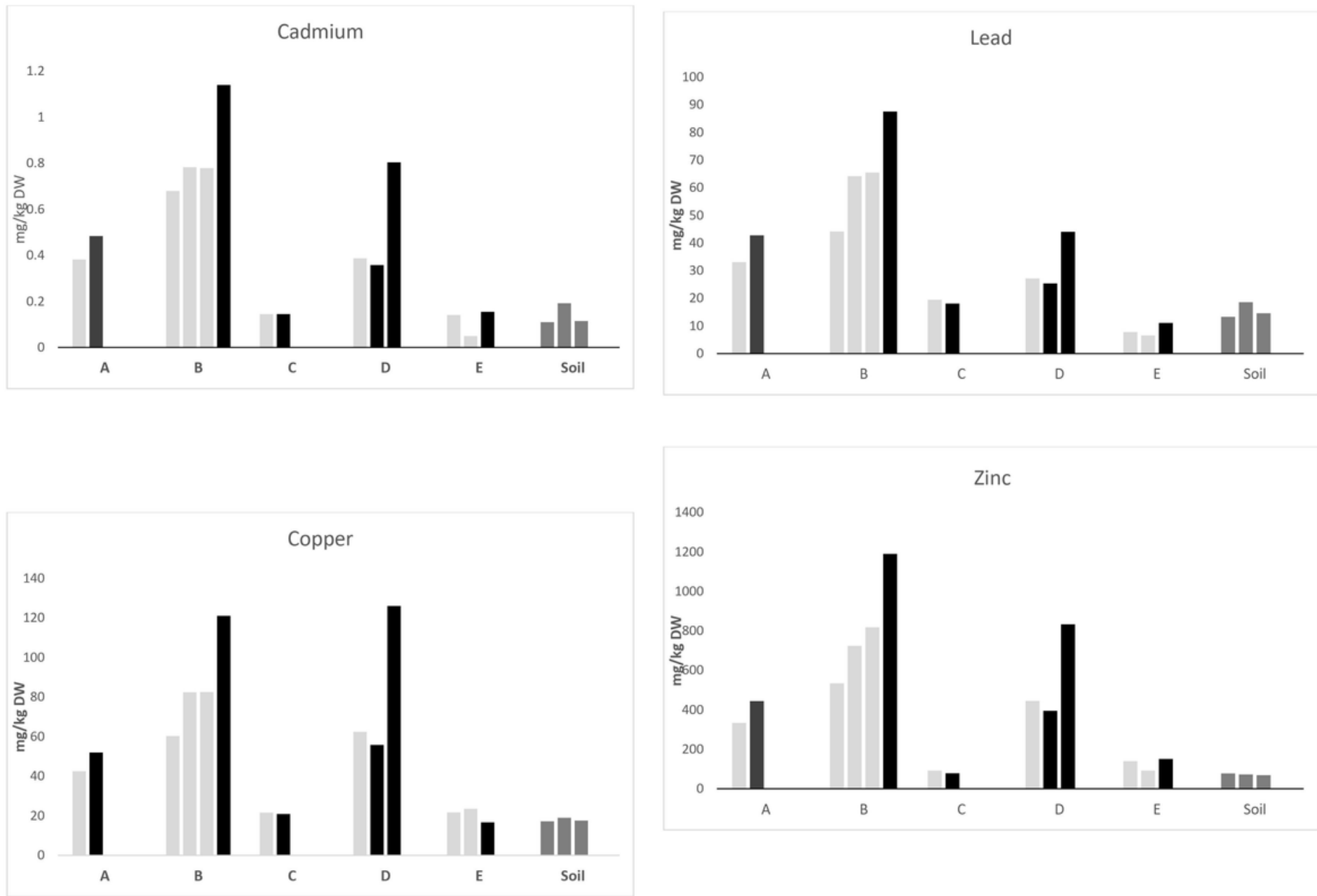

Figure 2

Concentrations of four commonly-monitored trace elements ( $\mathrm{Cd}, \mathrm{Co}, \mathrm{Pb}, \mathrm{Zn})$ in sediments in stormwater ponds and soil from the banks of the ponds in areas with industrial activity. Light grey bars - inlets, black bars-outlets. 

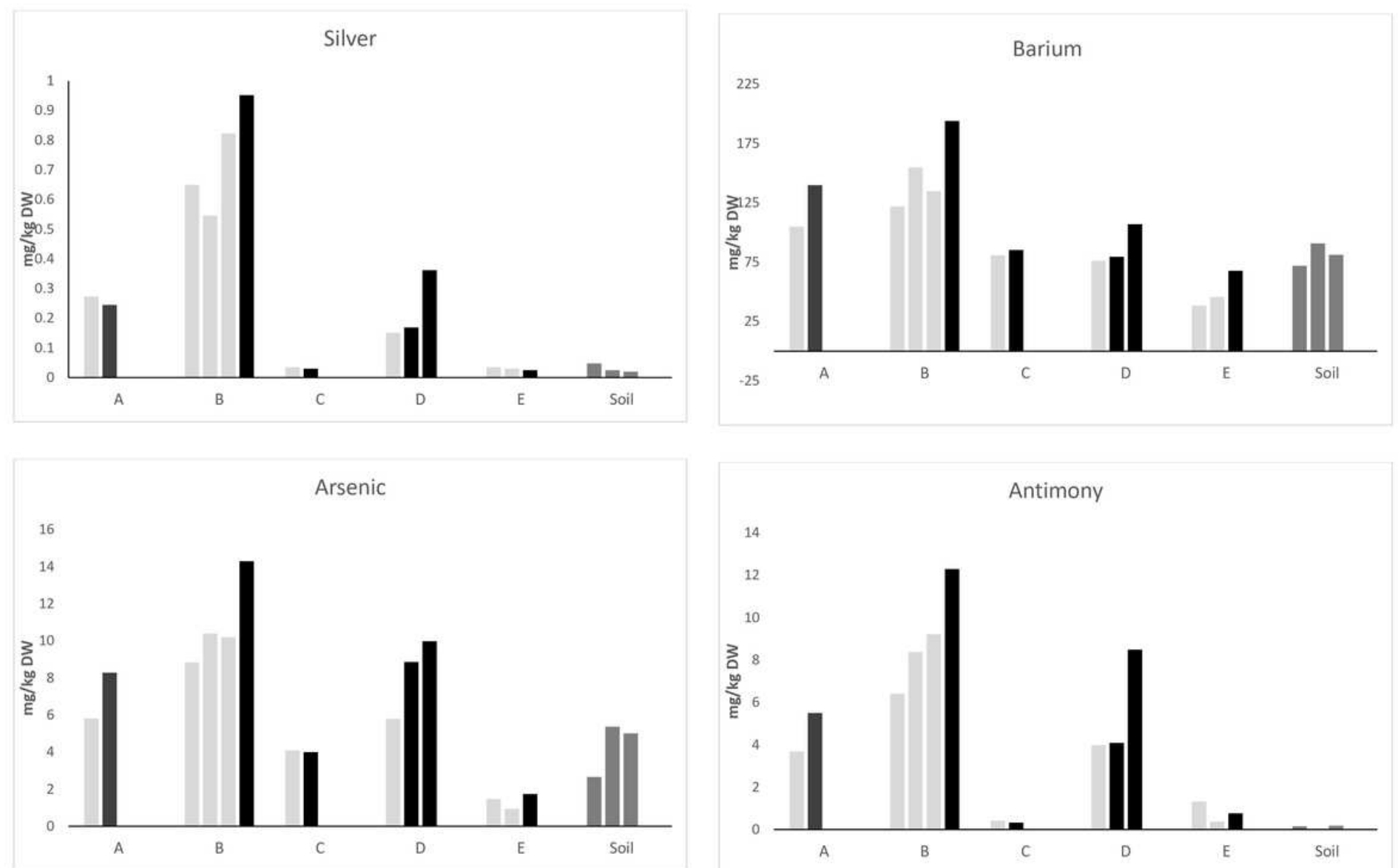

Figure 3

Concentrations of four seldom monitored trace elements ( $\mathrm{Ag}, \mathrm{As}, \mathrm{Ba}, \mathrm{Sb})$ in sediment in stormwater ponds and soil from the banks of the ponds in areas with industrial activity. Light grey bars - inlets, black bars-outlets 


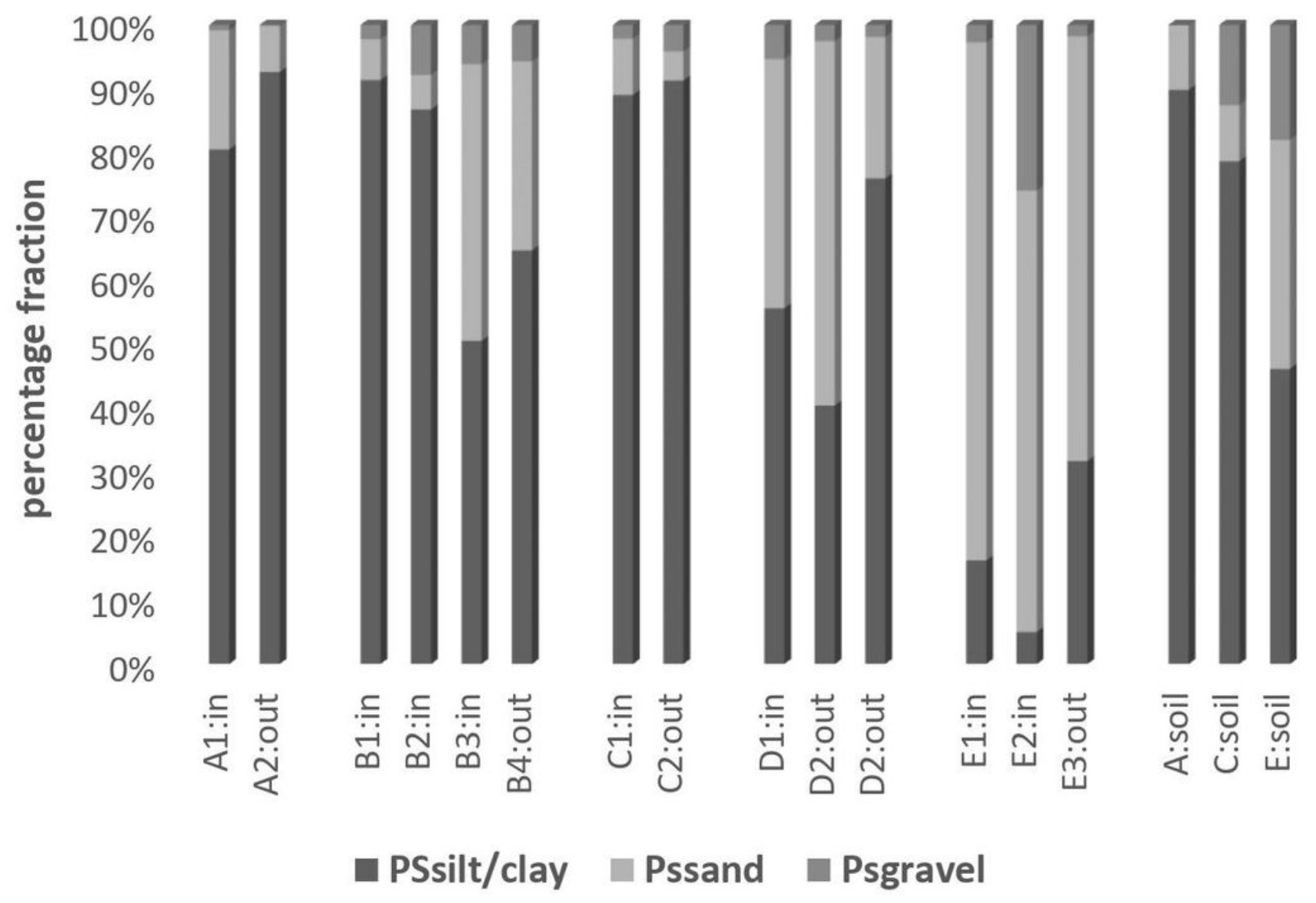

Figure 4

Particle size distribution of the sediment in the different sampling sites in five stormwater ponds. Particle size (PS) for PSsilt/clay $<0.063 \mathrm{~mm}$, PS sand $0.063-2 \mathrm{~mm}$ and PS gravel $>2 \mathrm{~mm}$ 

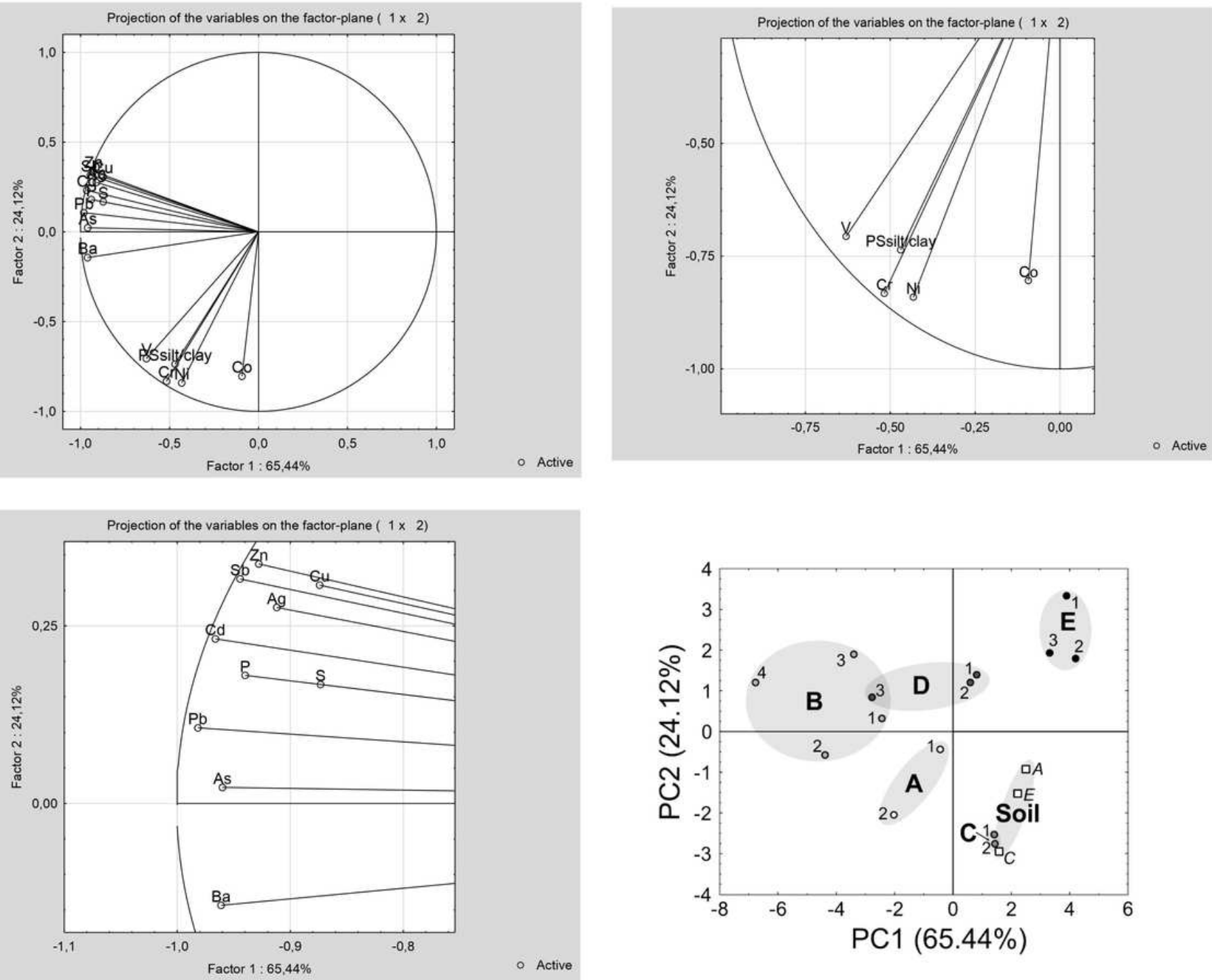

Figure 5

a) Projection of the variables on PC 1 and PC2. b) Enlarged section of PCA with Group A elements c) Enlarged section of PCA with Group B elements and PSsilt/clay d) Projection of the samples on PC1 and PC2 

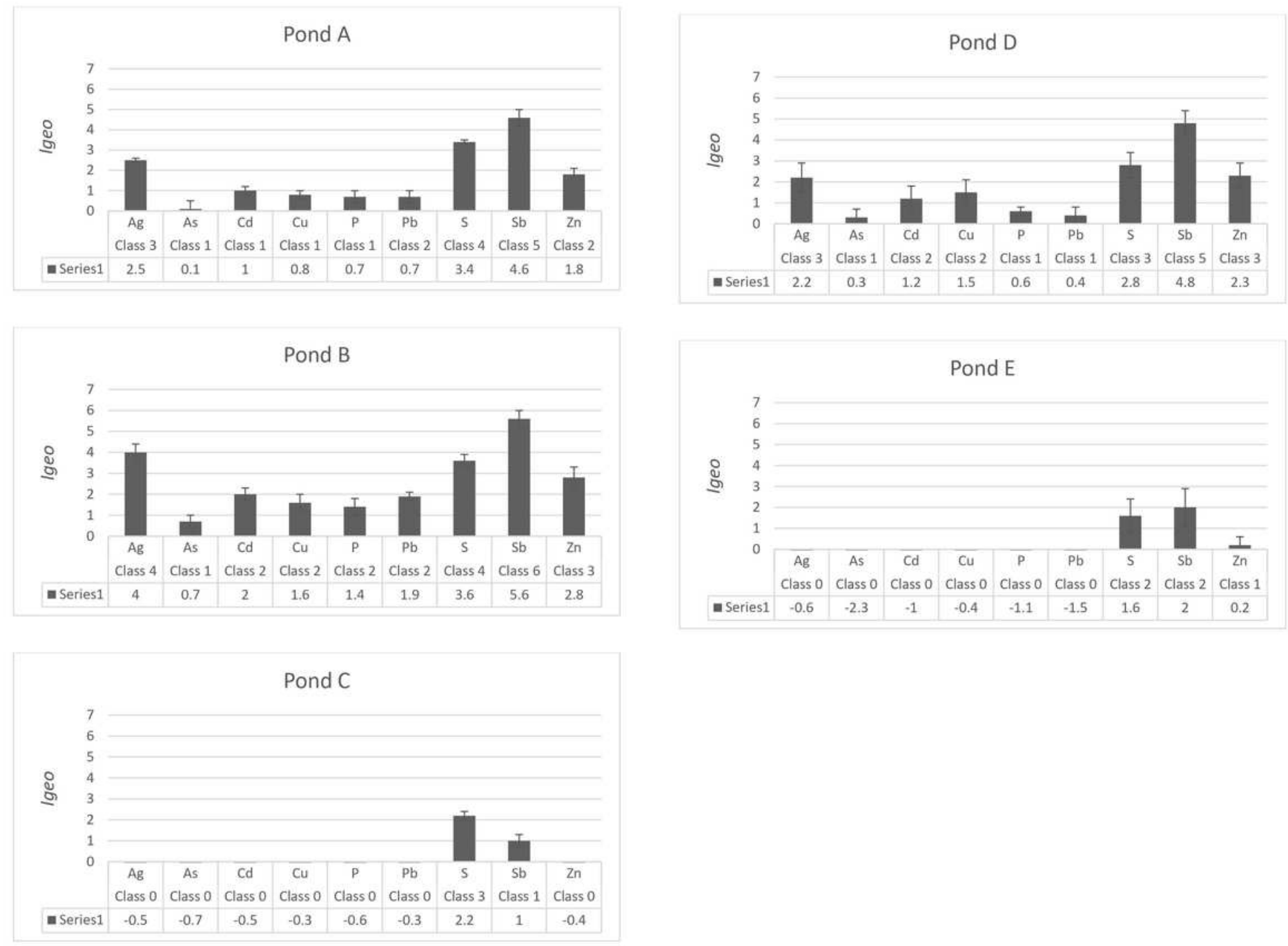

Figure 6

Contamination degree for trace elements in the different ponds using the geoaccumulation index Igeo. Classification was made using mean values, and error bars present standard deviation

\section{Supplementary Files}

This is a list of supplementary files associated with this preprint. Click to download.

- suppltablesdagdammsubmitted.docx 